\title{
Pendidikan Madrasah Berbasis 4.0 dalam Bingkai Manajemen Mutu
}

\author{
Samsul Bahri \\ Fakultas Tarbiyah dan Ilmu Keguruan \\ IAIN Kendari, Indonesia \\ smsulbahri1@gmail.com
}

\begin{abstract}
This paper examines 4.0-based madrasa education in a quality management frame with descriptive historical methods. This study discusses the world of madrasa education has many opinions, therefore, the application of the 4.0-based quality management system in improving quality to produce products that have cognitive and affective, psychomotor intelligence and maintain schools with distinctive characteristics of character and noble identity based on values religious values and being able to self-regulate in the 4.0 era. not maximal, it requires government policy by providing sufficient budget, so that madrasas can support their teachers, complete their educational facilities and infrastructure, provide digital-based textbooks, God willing, which can be easily resolved. The National Education System Law, which was passed several years ago, would provide an opportunity for the government to give adequate attention to all educational institutions, including madrasa education.
\end{abstract}

Keywords: Era 4.0, Madrasa Education, Quality Management

\begin{abstract}
Abstrak
Tulisan ini mengkaji pendidikan madrasah berbasis 4.0 dalam bingkai manajemen mutu dengan pendekatan sejarah dan metode deskriptif analitis. Studi ini menyimpulkan bahwa dunia institusi pendidikan madrasah mempunyai banyak persoalan, oleh karena itu, aplikasi pada sistem manajemen mutu yang berbasis 4.0 dalam meningkatkan kualitas untuk melahirkan produk yang mempunyai kecerdasan kognitif dan afektif, psikomotorik dan mempertahankan muatan madrasah dengan ciri khas pendidikan karakater dan jati diri luhur berlandaskan nilai-nilai agama dan mampu mendisrupsikan diri dalam era 4.0. belum maksimal, memerlukan kebijakan pemerintah dengan menyediakan anggaran yang cukup, sehingga madrasah dapat menghidupi para guru-gurunya, melengkapi sarana dan prasarana pendidikannya, menyediakan buku-buku pelajarannya yang berbasis digital, insya Allah persoalan ini dapat terselesaikan. Undang-Undang Sistem pendidikan Nasional yang
\end{abstract}


berhasil disahkan beberapa tahun lalu, kiranya memberikan peluang bagi pemerintah memberikan perhatian secukupnya terhadap seluruh lembaga penyelenggara pendidikan, termasuk pendidikan madrasah.

Kata Kunci: Era 4.0, Pendidikan Madrasah, Manajemen Mutu

\section{A. Pendahuluan}

Dalam sejarah pendidikan Islam di Indonesia, madrasah ${ }^{1}$ adalah institusi pendidikan yang sesunggunhya mempunyai peran dalam membangun peradaban anak bangsa. Hanya saja, dua institusi ini seringkali digeneralisasikan di Indonesia sama dengan sekolah, padahal secara historis berbedah, ${ }^{2}$ hal ini diakui oleh Husni Rahim bahwa persentuhan atau intraksi pendidikan Islam dengan Timur Tengah melahirkan madrasah, sedang intraksi atau pergumulan pendidikan Islam dengan Kolonial Belanda telah

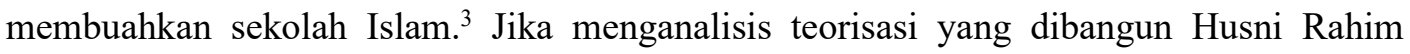
mengenai munculnya madrasah, maka modernisasi yang dilakukan Abdullah Ahmad di Minangkabau dan Muhammadiyah, bukan modernisasi madrasah tetapi sesungguhnya sekolah Islam. ${ }^{4}$ Oleh karena itu, madrasah sangat berperan dalam mencerdaskan kehidupan bangsa. lembaga pendidikan madrasah tersebut telah manjadikan pendidikan di Indonesia menjadi tersendiri dari sejarah dan kehidupan bangsa ini. Bahkan pertumbuhan dan perkembangannya dimulai dari tradisional sampai menjadi modern. Hal ini secara yuridis diatur dalam UUD 45.

Konsep pencerdasan kehidupan bangsa berlaku untuk semua komponen bangsa. Oleh karena itu UUD 1945 pada pasal 31 ayat (1) menyebutkan bahwa setiap warga negara

${ }^{1}$ Untuk mendapat informasi mengenai bagian ini lebih detail, lihat A. Karel A. Steenbrink, Pesantren, Madrasah, dan Sekolah, Jakarta, LP3ES, 1986. Lihat juga Badri Yatim dkk, Sejarah Perkembangan Madrasah, Jakarta, Depag RI, 1999. dan Martin van Bruinessen, Kitab Kuning, Bandung, Mizan, 1995.

${ }^{2}$ Dalam Perjalanan sejarah jalur pendidikan madrasah berbedah secara tajam dengan jalur sekolah umum baik dari perspektif melajutkan studi keperguruan tinggi maupun dalam persoalan lapangan kerja. Lihat Mastuhu, Memberdayakan Sistem Pendidikan Islam, Jakarta, Logos Wacana Ilmu, 1999, h. 57.

${ }^{3}$ Lihat Husni Rahim, Arah Baru Pendidikan Islam di Indonesia, h. 8.

${ }^{4}$ Sekolah Islam yang lahir dari gerakan koopratif dengan pendidikan Belanda. Seperti sekolah Adabiyah (bukan madrasah) yang menerapkan system klasikal denga konsekuen yang kemudian tahun 1915 lembaga ini berubah menjadi HIS Adabiyah yang merupakan sekolah Islam yang paling modern pertama di Indonesia. Untuk lebih jelas lihat Azyumardi Azra, Pendidikan Islam Tradisi dan Modernisasi Menuju Milinium Baru, Jakarta, Logos Wacana Ilmu, 2000, h. 37. lihat juga Mahmud Yunus, Sejarah Pendidikan di Indonesia, Jakarta, Pustaka Mahmudian, 1960. dan Karel A. Steenbrink, Pesantren, Madrasah, dan Sekolah, h. 35-83. 
berhak mendapatkan pendidikan, dan ayat (3) menegaskan bahwa pemerintah mengusahakan dan menyelenggarakan satu sistem pendidikan nasional yang meningkatkan keimanan dan ketakwaan serta akhlak mulia. ${ }^{5}$ Sebagai lembaga pendidikan yang sudah lama berkembang di Indonesia, madrasah selain telah berhasil membina dan mengembangkan kehidupan beragama di Indonesia, juga ikut berperan dalam menanamkan rasa kebangsaan ke dalam jiwa rakyat Indonesia.

Institusi madrasah pada era globalisasi yang menantang ini dihadapkan pada perubahan-perubahan yang menuntut adanya sistem keterbukaan politik, ekonomi, dan budaya. Era ini juga disebut dengan era persaingan bebas dan keunggulan teknologi informaasi. Semua aspek kehidupan akan berubah secara drastis yang beriringan dengan semakin tidak jelasnya batasan regional.

Tatanan masyarakat baru di atas akan melahirkan tuntutan-tuntutan dan tantangan baru pula. Tuntutan adanya keterbukaan dalam politik, pembagian kekuasaan serta sumber daya alam, menghargai hukum dan dan hak asasi manusia serta transparansi dalam kebijakan pemerintah akan semakin kuat. Atas dasar inilah maka memasuki era baru ini masyarakat menghendaki adanya dekosentrasi dan desentralisasi serta otonomi dalam mengambil kebijakan pembangunan. Keinginan ini telah dituangkan melalui UndangUndang No. 22 Tahun 1999 tentang Pemerintah Daerah. Undang-Undang No. 25 Tahun 1999 tentang pertimbangan Keuangan antara Pemerintah Pusat dan Daerah serta Peraturan Pemerintah No. 25 Tahun 2000 tentang Kewenangan Pemerintah dan Kewenangan Propinsi sebagai Daerah Otonom. ${ }^{6}$

Perbahan yang terjadi pada gilirannya akan mempengaruhi tata nilai kehidupan masyarakat yang mungkin sekali baru dan berbeda dengan gaya nilai yang sekarang dianut masyarakat. Pada proses perubahan ini kesiapan lembaga pendidikan dan institusi sosial lainnya menjadi sangat penting. Sebab masyarakat yang berada pada proses transisi kultural sangat labil pada berbagai benturan nilai. Dalam hal ini maka institusi pendidikan Islam khususnya lagi madrasah diharapkan dapat menjadi salah satu kekuatan yang dapat memberikan kontribusinya untuk pembentukan kultural Indonesia Baru yang berdasarkan pada nilai-nilai transendental. Pembinaan pendidikan yang dilakukan oleh Departemen

\footnotetext{
${ }^{5}$ Undang-Undang Dasar 1945, Pasal 31, Ayat 1 dan 3

6 Abdul Rachman Shaleh, Madrasah dan Pendidikan Anak Bangsa, (Jakarta: PT Raja Grafindo Persada, 2004), hal. 124.
} 
Agama selama ini masih perlu langkah-langkah penyesuaian yang strategis, utamanya dalam rangka mencari bentuk dan pemecahan masalah sehubungan dengan kemungkinan di berlakukannya Otonomi Daerah dan Desentralisasi di bidang pendidikan secara keseluruhan.

Usaha ke arah pengembangan pembinaan madrasah adalah sebagai kerangka dasar strategis pengembangan madrasah pada umumnya yang secara bertahap perlu dikembangkan sejalan dengan tuntutan dan perkembangan masyarakat yang penjabarannya lebih lanjut dituangkan dalam berbagai peraturan dan pedoman pelaksanaanya yang operasioanal. Pengembangan pembinaan madrasah dimaksudkan di dalamnya mencakup satu pilihan sistem, pendekatan, sumber dana dan sarana yang betul-beetul diperlukan untuk mencapai sasaran dan tujuan pembangunan.

Posisi strategis usaha pengembangan di bidang pendidikan pada madrasah sedikitnya dapat dilihat dari dua segi, yaitu:

1. Dari segi kedudukannya sebagai bagian integral dari kesatuan sistem Pendidikan Nasional. Dalam hal ini madrasah dituntut untuk mampu memenuhi tuntutan dan kebutuhan masyarakat, di samping harus memiliki hubungan yang akrab dengan sistem dengan sistem Pendidikan Nasional itu sendiri.

2. Dari segi kedudukannya sebagai bagian terpenting dari pembangunan sektor agama yang merupakan bagian integral dari pembangunan nasional. Dalam hal ini setiap upaya pengembangan madrasah harus mengacu agar madrasah dapat menunjang pembangunan sektor agama secara keseluruhan dengan tetap memelihara identitas dan kaakteristiknya sendiri sebagai sekolah agama dan lembaga keagamaan.7

Dengan demikian pengembangan pembinaan madrasah pada masa mendatang diorientasikan untuk menciptakan situasi yang kondusif agar dapat melakukan adaptasi dan akomodasi terhadap tuntutan program pendidikan dan tetap memelihara bobot dan identitas ciri kekhususannya sebagai lembaga pendidikan keagamaan. Makalah ini membahas madrasah berbasis 4.0 dalam bingkai manajemen mutu. Dengan menggunakan pendekatan sejarah dan metode deskriptif analisis.

\footnotetext{
${ }^{7}$ Abdul Rachman Shaleh, Madrasah dan Pendidikan Anak Bangsa, h. 126
} 


\section{B. Arah Desain Madrasah}

Jika memakai teori yang dibangun oleh Stanton dengan menyebut madrasah the institution of higher learning-lembaga keilmuan (pendidikan) tinggi, ${ }^{8}$ atau perguruan tinggi. Maka madrasah Nidzamiah yang didirikan di Baghdad oleh Nizam al-Mulk (awal abad ke-11/12 masehi)( 5-6 Hijriah) sebagai institusi formal pendidikan Islam adalah perguruan tinggi Islam bukan madrasah yang dipahami masyarakat Indonesia, ${ }^{9}$ tetapi madrasah di Indonesia merupakan sebagai cikal bakal perguruan tinggi Islam. Hal ini diakui oleh Abuddin Nata bahwa pendidikan suatu masyarakat atau negara tidak dapat diimpor atau diekspor dari atau kesuatu negara atau masyarakat. Ia harus timbul dalam masyarakat itu sendiri. Ia adalah pakaian yang harus ukur dan dijahit sesuai dengan bentuk ukuran pemakainya, berdasarkan identitas, pandangan, serta nilai-nilai yang terdapat dalam masyarakat atau negara tersebut. ${ }^{10}$ Walaupun demikian, tidak bisa diabaikan bahwa institusi madrasah mempunyai pengaruh dari jaringan Timur Tengah. Hal ini diakui Maksum mengakui bahwa sejarah madrasah di Indonesia merupakan konsekuensi pengaruh intensif pembaharuan pendidikan Timur Tengah masa modern. ${ }^{11}$

Bertolak dari kenyataan tersebut arah pengembangan pendidikan di madrasah bertujuan untuk dapat mengantarkan peserta didik menjadi manusia yang beriman dan bertakwa, berakhlak mulia, berkepribadian, menguasai ilmu pengetahuan dan teknologi, serta mampu mengaktualisasikan diri dalam kehidupan bermasyarakat berbangsa dan bernegara. 12

Spektrum tujuan pendidikan madrasah sebagaimana disebutkan di atas yang sejalan dengan kemajuan masyarakat memerlukan penjabaran bagi pelaksanaannya pada setiap jenis dan bidang pendidikan sebagaimana dikemukakan beriktu:

${ }^{8}$ Lihat Azyumardi Azra, “ Pendidikan Tinggi Islam dan Kemajuan Sains” dalam Charles Michael Stanton, Pendidikan Tinggi dalam Islam, Jakarta, Logos, 1994, h. vi

${ }^{9}$ Madrasah di Timur Tengah adalah lembaga pendidikan yang memberikan pelajaran ilmu agama tingkat lanjut sedang di Indonesia madrasah sebagai lembaga pendidikan yang memberikan pelajaran ilmu agama tingkat rendah dan menengah. Lihat Abdur Rachman Shaleh, Madrasah dan Pendidikan Anak Bangsa, Visi,Misi dan aksi, Jakarta, Raja Grafindo Persada, 2006, h. 12

10 Abuddin Nata, "Tantangan dan Peluang Pendidikan di Indonesia", dalam pidato pengukuhan Guru Besar, , h. 1 .

${ }^{11}$ Maksum, Madrasah dan Sejarah Perkembangannya, Jakarta, Logos, 1999, h. 81.

${ }^{12}$ Kementrian Agama, Desain Pengembangan Madrasah, (Jakarta: Direktorat Jendral Kelembagaan Agama Islam, 2005), hal. 18 
| SAMSUL BAHRI | Pendidikan Madrasah Berbasis 4.0 ...

1. Pendidikan dasar yang meliputi Madrasah Ibtidaiyah (MI) dan Madrasah Tsanwiyah (MTs) menekankan kemampuan umum yang diperlukan untuk hidup bermasyarakat dan bernegara. Menteri pendidikan tingkat dasar di madrasah ini lebih mengutamakan pada pembekalan kemampuan yang fungsional untuk kehidupan dalam berbagai bidang: sosial, budaya, ekonomi, dengan berbasis pada nilai-nilai ajaran agama Islam. Sejalan dengan semakin kompleksnya tantangan kehidupan, maka pendidikan dasar di Indonesia adalah sembilan tahun. Asumsinya adalah apabila pendidikan minimum ini tidak dicapai maka seseorang akan mengalami kesulitan dalam mengikuti perkembangan di sekelilingnya.

2. Pendidikan menengah yaitu Madrasah Aliyah (MA) memiliki tujuan utama yaitu mempersiapkan peserta didik untuk dapat melanjutkan pendidikannya pada jenjang perguruan tinggi.13

Dengan arah dan tujuan pendidikan sebagaimana tersebut di atas, maka acuan pemikiran dalam penataan dan pengembangan pendidikan madrasah harus mampu mengakomodasi berbagai pandangan dan pendapat secara selektif, sehingga terdapat keterpaduan dalam konsep pengembangannya. Beberapa prinsip dasar yang menjadi acuan dalam desain pengembangan madrasah antara lain:

1. Membangun prinsip kesetaraan antara sektor pendidikan madrasah sengan sektor pendidikan (di luar madrasah), dan dengan sektor-sektor lainnya. Kehadiran sistem pendidikan madrasah harus senantiasa dimaknai sebagai adanya keharusan untuk bersama-sama sistem lainnya mewujudkan cita-cita masyarakat.

2. Prinsip perencanaan pendidikan. Pendidikan madrasah bersifat progresif, tidak resisten terhadap perubahan, akan tetapi mampu mengendalikan arah perubahan itu.

3. Prinsip rekonstruksionis. Dalam kondisi masyarakat yang menghendaki perubahan mendasar artinya juga perubahan dengan skala besar berdasarkan gagasan besar, maka pendidikan madrasah juga harus mampu menghasilkan produk-produk yang dibutuhkan.

\footnotetext{
${ }^{13}$ Kementrian Agama, Desain Pengembangan Madrasah, hal. 19
} 
4. Prinsip pendidikan berorientasi pada peserta didik. Dalam memberikan pelayanan pendidikan sifat-sifat peserta didik yang bersifat umum maupun spsifik harus menjadi pertimbangan.

5. Prinsip pendidikan multibudaya. Sistem pendidikan madrasah harus memahami bahwa masyarakat yang dilayaninya bersifat plural, dan oleh karenanya pluralisme perlu menjadi acuan yang tak kalah pentingnya dengan acuan-acuan yang lain.

6. Prinsip pendidikan global. Pendidikan madrasah harus mampu berperan dalam menyiapkan peserta didik dalam konstelasi masyarakat global.14

Madrasah $^{15}$ merupakan institusi yang tumbuh dan berkembang oleh dan dari masyarakat, ${ }^{16}$ Indonesia seiring dengan masuk dan berkembangnya Islam di Indonesia. ${ }^{17}$ Kemunculan madrasah ${ }^{18}$ sebagai lembaga pendidikan Islam yang dimulainya dari bentuk pengajian, dirumah-rumah, terus ke mushallah, mesjid, majelis ta'lim sampai kebangunan

${ }^{14}$ Kementrian Agama, Desain Pengembangan Madrasah, hal. 21-23

${ }^{15}$ Beragam pengertian Madrasah Perkataan madrasah dalam bahasa Arab adalah bentuk kata ketetangan tempat (zharaf makan) dari akar kata "darasa" secara harfiah madrasah diartikan sebagai tempat belajar para pelajar atau tempat untuk memberikan pelajaran. Sedangkan Departemen Agama merumuskan arti madrasah melalui SKB 3 Menteri 1975 menjelaskan bahwa madrasah adalah lembaga pendidikan yang menjadikan mata pelajaran agama Islam sebagai mata pelajaran dasar yang diberikan sekurang-kurangnya 30\% di samping mata pelajaran umum. Dan dalam Undang-undang pendidikan Nasional No.2.tahun 1989, madrasah lembaga pendidikan yang berciri khas Islam. Uraian di atas dapat memberikan pengertian bahwa madrasah adalah lembaga pendidikan yang mempunyai tata cara yang sama dengan sekolah, mata pelajarannya agama Islam menjadi mata pelajaran pokok, di samping diberikan mata pelajaran umum, serta berciri khas Islam. Lihat Uraian Mehdi Nakosteen, Konstribusi Islam Atas Dunia Intelektual Barat; Deskripsi Analisis Abad Keemasan, edisi Indonesia, Surabaya, Risalah Gusti, 1996, h. 66. lihat juga, Ibrahim Anised, al-Mu'jam al-Wasit, Kairo, Dar al-Ma'arif, 1972, h. 280. Lihat Lihat Surat Keputusan Bersama 3 Menteri (SKB 3Menteri), tahun 1975 pasal I.

16 Commnity based education, merupakan kebijakan yang memberikan keluasan bagi masyarakat untuk ikut serta berperan dalam bidang pendidikan sesuai dengan kebutuhan masyarakat sekitarnya.

${ }^{17}$ Madrasah, dalam peta dunia pendidikan Indonesia, memang bukan sesuatu yang indigenous, sebagai ditunjukkan oleh kata madrasah itu sendiri yang berasal dari bahasa Arab. Lihat Husni Rahim, Rahim Husni, Madrasah dalam Politik Pendidikan di Indonesia, Jakarta, logos, 2005, h. 10 .

${ }^{18}$ Dilihat dari sejarahnya setidak-tidaknya ada dua faktor penting yang melatarbelakangi kemunculan madrasah, yaitu: pertama, adanya pandangan yang mengatakan bahwa sistem pendidikan Islam tradisional dirasakan kurang bisa memenuhi kebutuhan pragmatis masyarakat; Kedua, adanya kekhawatiran atas cepatnya perkembangan persekolahan Belanda yang akan menimbulkan pemikiran sekular di masyarakat. Untuk menyeimbangkan perkembangan sekularisme, maka masyarakat muslim-terutama para reformis, yang berusaha melakukan reformasi pengembangan pendidikan dan pemberdayaan madrasah. Lihat Muhaimin, Pengembangan Kurikulum Pendidikan Agama Islam, di Sekolah, Madrasah, dan Perguruan Tinggi, Jakarta, Raja Grafindo Persada, 2007, h. 183. 
madrasah seperti yang kita kenal saat ini, dengan menggunakan sistem tradisional. ${ }^{19}$ Bahkan modernisasi madrasah terus bergulir untuk mencari format madrasah ${ }^{20}$ yang ideal, untuk menjadikan madrasah fungsional sebagai salah satu lembaga layanan pendidikan bagi kebutuhan masyarakat yang terus berubah. A. Malik Fajar misalnya memberikan penjelasan bahwa dalam meyongsong perubahan madrasah, maka kebijakan-kebijakan perlu diakomodasi berbagai kepentingan masyarakat. ${ }^{21}$ Demikian halnya dengan Azyumardi Azra berpendapat bahwa institusi madrasah seharusnya mengkaji ulang secara cermat gagasan reposisi madrasah, terutama dalam konteks kekinian. Sebab, bukan tidak

${ }^{19}$ Lihat Husni Rahim, Rahim Husni, Madrasah dalam Politik Pendidikan di Indonesia, h. 10. lihat juga A. Karel A. Steenbrink, Pesantren, Madrasah, dan Sekolah, h. 10. Sebagai penjelasan tambahan lihat. Mahmud Yunus, Sejarah Pendidikan Islam di Indonesia, Jakarta, Hidakarya Agung, 1993, h. 34.

20 Sejarah madrasah di Indonesia yang pernah ada atau model-model madrasah yakni Madrasah Wajib Belajar (MWB), dari sinilah selanjutnya dinamika lembaga madrasah menyebabkan lahirnya beberapa model madrasah yang antara lain: (a) Madrasah swasta dan negeri, (b) madrasah model adalah madrasah konvensional yang diterapi secara khusus untuk menjadi model madrasah yang berkualitas, sehingga dapat menjadi contoh bagi madrasah negeri dan swasta untuk menggerak-kan dan meningkatkan kualitas madrasah lain didaerah, (c) madrasah terpadu adalah suatu madrasah yang ingin memberikan konsep keterpaduan dengan melihat madrasah ibtidayah, tsanawiyah, aliyah yang berada dalam satu lokasi sebagai satu kesatuan disekolah. Di mana seluruh aspeknya, kurikulum, proses belajar mengajar, perpustakaan, guru, fasilitas pendidikan dapat dipadukan sebagai satu kesatuan berkesinambungan satu sama lain. Dengan kata lain memadukan konsep madrasah unggul dengan madrasah model, (d) model Madrasah Aliyah Keagamaan (MAK) adalah model madrasah aliyah program khusus sebagai upaya mempetahankan madrasah aliyah program ilmu-ilmu agama yang diharapkan menghasilkan siswa yang memiliki kemampuan dasar ilmu agama, bahasa arab yang diperlukan untuk melanjutkan keperguruan tinggi, (e) madrasah aliyah program keterampilan (MAPK) adalah madrasah aliyah yang diberi tambahan program ekstrakurikuler dalam berbagai bidang keterampilan yang terstruktur, (f) model madrasah dan sekolah pondok pesantren adalah model pondok pesantren yang memberi respon terhadap tuntutan kebutuhan masyarakat. Dengan begitu, dunia pesantren, di mana keterpaduan madrasah dengan nuansa Iptek dan sekolah dengan nuansa agama menjadi suatu kebutuhan ditambah lagi dengan sistem asrama, (g) model madrasah sekolah dengan bording school adalah model madrasah sekolah yang muncul dengan menggunakan sistem pesantren. Suatu sistem yang menekankan metode pengajaran yang diorientasikan pada penguasaan substansi materi keilmuan (bukan target kurikulum). Lihat Mulyanto Sumardi, h. 46-54. lihat juga Husni Rahim, Rahim Husni, Madrasah dalam Politik Pendidikan di Indonesia, h.159-192.

${ }^{21}$ Oleh karena itu ada tiga kepentingan: Pertama, Kebijakan itu harus memberi ruang tumbuh yang wajar bagi aspirasi utama umat Islam, yakni menjadikan madrasah sebagai wahana untuk membinah ruh atau praktek hidup islami. Kedua, kebijakan itu menjelaskan dan memperkukuh keberadaan madrasah sebagai ajang membina warga negara yang cerdas, berpengetahuan, berkepribadian serta produktif sederajat dengan sistem sekolah. Porsi dari kebijakan ini tidak lain agar pendidikan madrasah sanggup mengantarkan peserta didik memiliki pengusaan secara memadai, yaitu penguasaan pengetahuan dan kemampuan dasar dalam bidangbidang umum. Ketiga, kebijakan itu harus bisa menjadikan madrasah mampu merespon tuntutantuntutan masa depan. Lihat A. Malik Fajar, Reorintasi Pendidikan Islam, Jakarta, Fajar Dunia, 1999, h. 95-96. 
mungkin orientasi semacam itu menimbulkan implikasi negatif terhadap eksistensi dan fungsi pokok madrasah itu sendiri. ${ }^{22}$

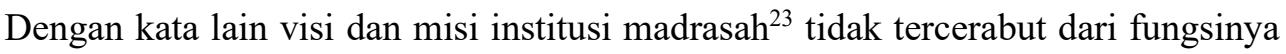
yang berbasis sekolah tafaqqun fid dien dan juga tidak ketinggalan terhadap semua perkembangan yang terjadi di masa kontemporer dan era globalisasi, sehingga institusi madrasah dapat diwujudkan sebagai wahana peradaban modern. Bahkan menurut A. Malik fajar pelajar keluaran madrasah diharapkan menjadi sumber daya manusia yang memiliki pengetahuan dan penguasaan ilmu pengetahuan dan teknologi secara memadai, serta memiliki daya kreativitas yang tinggi. ${ }^{24}$ Oleh karena itu, untuk mencapai hal tersebut menurut Mastuhu dan Abdur Rahman Shaleh ${ }^{25}$ perlu memperbaharui sistem pendidikan

${ }^{22}$ Harus dipahami bahwa dengan menyatakan hal ini, tidak berarti madrasah harus tidak peduli sama sekali terhadap perkembangan di luar dunianya. Sebaliknya madrasah harus menumbuhkan apresiasi dan memberikan respon sepatutnya terhadap semua perkembangan yang terjadi di masa kini dan mendatang . Lihat Azyumardi Azra, Paradigma Baru Pendidikan Nasional Rekonstruksi dan demokratisasi, Jakarta, Kompas, 2002, h. 94.

${ }^{23}$ Visi madrasah yang pertama Islami yang mencerminkan pendidikan madrasah sebagai lembaga pendidikan yang suasana dan kehidupan para peserta didik, pendidik, kurikulum, dan para penghuni lainnya mengamal ajaran Islam dengan baik. Visi yang kedua, populis yakni institusi ini merupakan pesan utama dari sejarah pendidikan Islam di Indonesia dari masa ke masa. Sejak periode paling dini, madrasah lahir dan berkembang dengan dukungan masyarakat serta terbuka bagi semua lapisan social. Visi ketiga, berkualitas artinya berorientasi pada mutu. Visi keempat, beragam artinya beragam pada madrasah menunjukkan adanya fleksibilitas dalam pelaksanaan pendidikan. Madrasah sangat menghargai keragaman bentuk dan jenis pendidikan. Lihat Husni Rahim, Rahim Husni, Madrasah dalam Politik Pendidikan di Indonesia, h. 40-46.

${ }^{24}$ Lihat A. Malik Fajar, Visi Pembaharuan Pendidikan Islam, Jakarta, LP3NI, 1998, h. 122123.

${ }^{25}$ Menurut Abdur Rahman Shaleh reposisi dunia madrasah dalam memasuki era Indonesia Baru ada beberapa hal harus dibenahi: Pertama, pengembangan madrasah dalam mewujudkan visinya, maka madrasah mengembangkan misi untuk menjadikan madrasah yang islami, populis, dan berkualitas. Dimaksudkan dengan Islami, yaitu madrasah yang berciri khas Islam, yang mampu menciptakan anak bangsa yang beriman dan bertaqwa kepada Allah Swt, dan berakhlak mulia. Dimaksudkan dengan populis yakni madrasah yang selalu dicintai oleh masyarakat karena tumbuh dan berkembang dari, oleh dan untuk masyrakat, serta lulusannya memmiliki relevansi dengan kebutuhan masyarakat. Selajutnya dimaksudkan dengan berkualitas, yaitu madrasah yang mampu mencetak anak bangsa yang memiliki kemapuan dan keterampilan yang cukup dan sanggup menghadapi tantangan zaman. Kedua, hidup dan berkembangnya madrasah akan bergantung seberapa besar kesadaran umat Islam untuk memelihara kelangsungannya yang harus dibangun berbasis kekuatan masyarakat. Sementara itu dalam hal penyelenggaraan madrasah menekankan tugas pembinaan kea rah school based management terbuka sesuai dengan tuntutan masyarakat yang semakin maju dan berkembang secara demokratis. Ketiga, madrasah dalam posisinya memasuki era Indonesia baru, dunia madrasah memerlukan dinamika di bidang pengembangan ilmu pengetahuan dan teknologi. Keempat, penyelenggaraan madrasah pada gilirannya harus mampu memperbaiki sistem manajerial kualitas sumber daya tenaga kerja pendidikan, sarana prasarana(perpustakaan, laboratorium computer, workshop keterampilan) dan meningkatkan sumber 
madrasah, ${ }^{26}$ sehingga kelemahan madrasah bisa diatasi, ${ }^{27}$ sehingga lembaga yang mempunyai karakteristik ${ }^{28}$ sendiri dibanding dengan sekolah menjadi pilihan umat Islam.

pembiayaan melalui peningkatan peran serta masyarakat pendukungnya. Kelima, pembiyaan pendidikan bagi setiap anak bangsa Indonesia belum diperlakukan secara adil dalam memberi layanan pendidikan dan pengalokasian anggaran, antara lain adanya pembedaan pembiyaan pendidikan dan unit cost perkapita siswa antara siswa sekolah umum dan siswa madrasah. Keenam, peningkatan kualitas mutu pendidikan pada madrasah dalam memasuki masyarakat pada era Indonesia baru harus dilaksanakan untuk memperkuat dan memperkokoh misi, fungsi dan tugas pokok agar madrasah setara(tidak perlu sama) pada semua jenjang, jenis, dan jalur pendidikan dengan sekolah umum. Di masa mendatang pada era Indonesia Baru harus dapat dihapuskan dikotomi antara sekolah swasta dan sekolah negeri. Kebijaksanaan manajerial pendidikan perlu diserahkan kepada sekolah. Demikian pula dalam hal pembiyaan oprasional pendidikan bagi sekolah swasta perlu ditingkatkan dan diberikan prioritas dalam menentukan sasaran strategisnay. Lihat Abdur Rahman Shaleh, Madrasah dan Pendidikan Anak Bangsa; Visi, Misi dan Aksi, Jakarta, Rajagrafindo Persada, 2006, h. 77-79.

${ }^{26}$ Mastuhu mengusulkan untuk perbaikan madrasah:Pertama, kurikulum 1994 tidak akan mampu mancapai tujuan ideal, yang antara lain, hilangnya dikotomi antara ilmu agama dan ilmu umum, apabila tidak disertai dengan konsep ilmiah; bagaimana mengitrasikan keduanya. Kedua, diusulkan setiap mata pelajaran di sekolah manapun harus dilihat dari dua sisi: sebagai alat dan tujuan. Misalnya, mata pelajaran biologi. Ia bisa dijadikan sebagai alat untuk menumbuhkembangkan Imtaq (iman dan taqwa), tatapi dapat juga dipandang sebagai tujuan untuk menjadi dasar pengembangan ilmu kedokteran. Ketiga, perlu dibudayakan penggunaan istilahistilah baru sebagai pengganti istilah-istilah lama yang menunjukkan adanya dikotomi. Misalnya, tidak menggunakan istilah fakultas agama dan fakultas umum atau fakultas non agama. Lebih tepat digunakan istilah-istilah fakultas ushuluddin, dakwa, tarbiyah, syariah, adab, sebagaimana nama fakultas kedokteran, ekonomi, dan psikologi. Jadi sebut saja dengan nama program studi. Keempat, pendidikan Madrasah Ibtidaiyah, Tsnawiyah dan Aliyah tidak berdiri sendiri. Di atas dan di bawahnya, di kanan dan di kirinya, ada sub system yang sangat menentukan keberhasilan misi pendidikan madrasah. Lihat Mastuhu, Memberdayakan Sistem Pendidikan Islam, Jakarta, Logos, 1999, h. 61-62.

${ }^{27}$ Kelemahan sistem pendidikan madrasah yaitu: (1) mementinkan materi di atas metodologi, (2) memetingkan memori di atas analisis dan dialog, (3) memetingkan pikiran vertical/linear diatas lateral, (4) mementingkan penguatan otak kiri di atas otak kanan, (5) materi pelajaran agama yang diberikan masih bersifat tradisional belum menyentuh aspek rasional, (6) penekanan yang berlebihan pada ilmu sebagai produl final, bukan pada proses metodologinya dan(7) mementingkan orientasi memiliki di atas menjadi. Lihat Mastuhu Memberdayakan Sistem Pendidikan Islam, h. 59.

${ }^{28}$ Karakteristik madrasah adalah ciri khas yang melekat pada madrasah yang merupakan kekuatan dari madrasah itu sendiri. Karakteristik madrasah meliputi pertama, Madrasah adalah milik masyarakat (Community Based Education). Madrasah tumbuh dan berkemabang dari masyarakat dan untuk masyarakat, karena itu dari segi kuantitas berkembang sangat pesat namun dari segi kualitas perkembangan madrasah sangat lamban. Konsekwensi madrasah yang bersifat "populis/massif" yang selalu cenderung memekar dan belum sempat mendalam. Keterikatan masyarakat terhadap madrasah lebih dinampakkan sebagai ikatan emosional keagamaan yang tinggi. Ikatan ini muncul karena bertemu dua kepenting-an, yakni hasrat kuat masyarakat untuk berperang serta dalam pendidikan dan motivasi keagamaan untuk tafaqqun fid dien, dengan kekuatan ini, akhirnya masyarakat mempunyai rasa memiliki (sence of biloging) dan rasa tanggung jawab (sence of responsibility) yang tinggi dan dapat menjamin keberlangsungan madrasah. Tetapi dipihak lain madrasah menjadi kendala karena merasa sebagai pemilik dan pendiri. Dan tidak muda ide-ide reformasi. Kedua, madrasah sebagai manajemen berbasis sekolah (school based 
Sehubungan dengan itu, Azyumardi Azra memberikan penjelasan bahwa kurikulum madrasah seharusnya memiliki dua komponen yakni pendidikan umum dan pendidikan Islam. ${ }^{29}$ dan dapat terintegrasikan atau memimjam istilah Suwito, terciptanya integrasi ilmu-ilmu yang bersumber pada ayat- ayat qur'aniyyah dan ilmu-ilmu yang bersumber ayat-ayat kauniyyah. Ilmu-ilmu yang bersumber dari ayat-ayat qur'aniyyah disebut ilmu agama dan ilmu yang bersumber dari ayat-ayat kauniyyah disebut ilmu umum. ${ }^{30}$ Dengan demikian tujuan lembaga pendidikan madrasah ${ }^{31}$ dapat tercapai.

Management). konsep manajemen berbasis sekolah merupakan konsep yang memberikan kewenagan, kepercayaan dan tanggung jawab yang luas bagi sekolah berdasarkan profesionalisme untuk menata organisasi sekolah, mencari dan mengembangkan serta mendayagu-nakan sumber daya pedidikan yang tersedia, dan memperbaiki kinerja sekolah dalam upaya meningkatkan mutu pendidikan atau sekolah yang bersangkutan. Madrasah sejak awal kemuculannya didasari shool based management. Keberanian madrasah menentukan jenis keunggulan apa dari madrasahnya dan ciri khas apa yang membedakan dengan madrasah lain. Keragaman dan ketidak ketergantungan dengan pemerintahan pusat dan birokrasi telah membuat madrasah pada masa lalu, banyak yang bergensi. Ketiga, madrasah sebagai lembaga tafaqqun fin dien, konsep dasar dari madrasah adalah untuk memberi kesempatan pada peserta didik mempelajari dan memahami serta mendalami agama sebagai kewajiban dari setiap individu, kemudian meneruskan ilmu yang didapat kepada orang lain. Ini pulalah yang menyebabkan madrasah tidak dapat dipisahkan dari lembaga dakwah yang bukan fokus utamanya. Keempat, madrasah sebagai lembaga kaderisasi dan mobilitas umat, dari proses pendidikan ini melahirkan pribadi muslim yang saleh dengan penguasaan dan pengalaman ajaran Islam yang luas, mendalam, dan konsisten. Lihat Husni Rahim, Madrasah Dalam Politik di Indonesia, 38-40.

29 Paradigma pengembangan dan penerapan kurikulum berbasis kompetensi seharusnya menjadi titik tolak pembaharuan kurikulum sistem pendidikan madrasah secara keseluruhan. Kebutuhan pembaharuan bagi sistem pendidikan madrasah ini mutlak dilakukan, bukan hanya dalam konteks membangun sistem pendidikan Islam yang distingtif, tetapi juga sekaligus membangun dan mengembangkan keunggulan(excellence)atau quality education vis a vis sistem pendidikan umum secara keseluruhan. Dalam era otonomi dan desentralisasi, pembaharuan kurikulum jelas relevansinya, jika sistem pendidikan Islam ingin memberikan sumbangan yang lebih bermakna dan signifikan bagi lingkungannya. Lihat Azyumardi Azra, Paradigma Baru Pendidikan Nasional Rekonstruksi dan demokratisasi, h. 95-99.

${ }^{30}$ Lihat Suwito, "Kurikulum Berbasis Kompetensi", dalam makalah seminar sambutan atas nama Rektor UIN Syarif Hidayatullah, Jakarta, pada acara Workshop, pada Program Studi Agribisnis Fakultas Sains dan Teknologi, Jakarta, 17 April 2003, h. 1 Secara sederhana beliau menjelaskan sebagai berikuat:

a) Historical Content Setiap Pendidik hendaknya menjelaskan sejarah lahir dan perkembangan ilmu yang sedang dipelajari sejak awal pertumbuhan sampai sekarang.

b) Theorical Content Hal ini masih terkait dengan yang di atas pendidik harus dapat menampilkan teori-teori yang pernah dikemukakan oleh para ahli dari masa ke masa. Dengan demikian akan merangsang para peserta didik untuk memperdalam ilmu tersebut. Dan bahkan memiliki keberanian untuk mengembangkan agar memperoleh hal yang baru.

c) Practical Conten Setiap bidang ilmu juga perlu penjelasan dari sisi kegunaan praktisnya untuk kepentingan kehidupan. Dengan cara ini diharapkan para peserta didik dapat mengambil manfaatnya setelah mempelajari bidang studi tersebut. 
Namun demikian, menurut Arif Furcon menjelaskan madrasah mempunyai banyak kelemahan dan problem, persoalan utama yang dihadapi oleh kebanyakan madrasah dewasa ini adalah kualitas lulusan yang masih jauh dari harapan, terutama di bidang ilmu dan keterampilan. Indikator paling mudah (dan sebetulnya paling rendah) adalah NEM. Secara nasional, NEM rata-rata madrasah masih tergolong rendah (di bawah 6). Ini berarti lulusan madrasah belum memiliki dasar yang kokoh (di bidang ilmu, ketrampilan, dan mental agama) untuk dikembangkan. ${ }^{32}$ Ada beberapa penyebab:

1. Kepemimpinan pengurus yayasan dan Kepala Madrasah masih memprihatinkan. Karena sejarah pendirian kebanyakan madrasah yang merupakan inisiatif masyarakat dan didorong untuk ikut berpartisipasi dalam pendidikan generasi muda Muslim, maka kebanyakan pengurus yayasan yang mengelola madrasah tidak memiliki pengetahuan dasar kependidikan modern, terutama dalam bidang kepemimpinan dan manajemen madrasah. Demikian pula dalam hal pemilihan Kepala Madrasah. Berbagai keterbatasan telah mengakibatkan banyak Kepala Madrasah yang kurang memiliki pengetahuan dan ketrampilan untuk memimpin dan mengelola madrasah agar dapat menghasilkan lulusan yang mampu bersaing dengan lulusan sekolah/madrasah lainnya atau yang mampu memberikan sumbangan kepada masyarakat untuk memecahkan problem yang mereka hadapi.

2. Kurikulum kebanyakan madrasah tampaknya masih kurang efektif, relevan, efisien, dan luwes. Kurikulum masih terlalu banyak ditentukan oleh Pusat dan

d) Case Content Masih terkait dengan butir c di atas, setiap bidang ilmu perlu dijelaskan pula beberapa studi kasus yang terkait dengan ilmu tersebut. Dengan demikian setiap pendidik mampu memberikan contoh kasus dalam kaitan manfaat praktis suatu bidang ilmu.

e) Science and Tecnologi Content Banyak ayat al-Qur'an yang memerlukan penjelasan dan sisi sains dan teknologi, bukan hanya sisi bahasa dan sastra Arab, ushul fiqh, tajwid atau ilmu yang selama ini dikenal sebagai ilmu agama. Selain akan menjadi lebih jelas, pendekatan secara sains dan teknologi dalam menjelaskan ayat-ayat al-Qur'an dan Hadis akan lebih memperkuat keyakinan untuk berislam dan mengembangkan ilmu pengetahuan.

f) Islamic Content Atas dasar keyakinan bahwa semua ilmu dan lainnya yang ada dialam ini berasal dari Yang Maha Satu, maka antara ilmu yang sekarang dikenal sebagai ilmu agama tak mungkin bertentangan dengan ilmu yang kini diyakini dengan ilmu umum.

${ }^{31}$ Adapun tujuan didirikan madrasah yakni untuk mentransmisikan nilai-nilai Islam, untuk memenu-hi kebutuhan modernisasi pendidikan. Lihat Hanun Asrohah, Sejarah Pendidikan Islam di Indonesia, Jakarta, Logos wacana Ilmu, 2001, h. 192-193.

${ }^{32}$ Disampaikan pada Pelatihan Supervisi Pendidikan Madrasah Ibtidaiyah dan Tsanawiyah Tahun 2001, BEP Depag di Pusat Pendidikan Infantri, Bandung.2 Sekretaris Ditjen Kelembagaan Islam, Depag. 
Pusat tampaknya kurang memberikan kebebasan kepada madrasah untuk menyesuaikan kurikulum itu dengan kebutuhan masyarakat di daerahnya. Padahal, kalau ada masalah dengan kualitas lulusannya, madrasah itulah yang akan menjadi sasaran keluhan dan protes masyarakat yang menyekolahkan anaknya ke madrasah itu.

3. Proses Belajar Mengajar (PBM) di kebanyakan madrasah belum merangsang kreativitas siswa dan tidak mendorong siswa untuk beraspirasi kepada keberhasilan dan kebiasaan (etos) kerja yang baik.

4. Fasilitas belajar di kebanyakan madrasah, terutama perpustakaan, masih kurang mendukung proses belajar mengajar.

5. Lingkungan belajar di kebanyakan madrasah masih belum dapat mendukung proses belajar mengajar yang baik.

6. Input siswa yang kebanyakan bermutu rendah dan kurang/tidak adanya program remedial untuk membantu siswa yang belum siap untuk mengikuti program pendidikan yang diberikan di madrasah.

7. Terlalu dominannya peran pemerintah sehingga kebanyakan madrasah bersikap pasif dan sangat menggantungkan diri pada inisiatif pembinaan pemerintah (kurang memiliki inisiatif sendiri) untuk meninngkatkan mutu lulusannya.

8. Kurangnya dana operasional dan pengembangan madrasah. Hal ini diperparah lagi dengan kurangnya pengetahuan dan ketrampilan kebanyakan pengurus yayasan dan Kepala Madrasah dalam hal membuat rencana strategis pengembangan madrasah, penggalian dana, dan pengelolaan keuangan.

Di samping itu, faktor penghambat pengembangan madrasah juga masalah klasik yang tetap aktual karena masih sering dipersoalkan oleh para pakar pendidikan Islam adalah adanya dikotomi dalam sistem pendidikan. Dualisme dikotomik ini nampaknya sudah berkembang dan dianggap sebagai sistem pendidikan modern yang sesuai dengan zaman. Sebenarnya hal ini tidak boleh terjadi, karena dualisme dikotomik yaitu sistem pendidikan Barat yang dinasionalisasikan dengan menambah beberapa mata pelajaran agama (Islam) dan sistem pendidikan (Islam) yang berasal dari zaman klasik (tradisional) yang tidak diperbaharui secara mendasar, mempunyai arah yang berbeda atau dalam beberapa sisi penting justru bertolak belakang. Permasalahan yang dihadapi madrasah pada umumnya juga merupakan permasalahan yang dihadapi pendidikan Islam. 
Sementara permasalahan pendidikan Islam bukan hanya menyangkut persoalan dalam kelas tetapi juga meliputi masalah dakwah Islam dan pembangunan sistem kehidupan umat yang Islam, sebagai peradaban Islam alternatif. Pola hubungan tiga masalah pokok yang dimaksud secara global dapat dijelaskan bahwa bentuk aktivitas dakwah Islam yang tidak bisa menyajikan Islam secara kaffah menyebabkan sistem pendidikan ini dikotomik. Sistem pendidikan yang dikotomik menyebabkan lahirnya sistem pendidikan umat Islam yang sekularistik, rasionalistik-empiristik, intuitif dan materialistik, dan keadaan tersebut tidak mendukung tata kehidupa umat yang mampu melahirkan peradaban Islami.

Sementara itu, Ahmad Watik Pratiknya (1991) mencatat bahwa sungguhpun umat Islam mempunyai tradisi dan lembaga-lembaga kependidikan yang cukup luas dengan makin berkembangnya kehidupan sosial budaya masyarakat Indonesia, dalam potret masa kini dirasakan adanya ketertinggalan sistem pendidikan umat yang tercermin dengan berbagai permasalahannya yang secara langsung maupun tidak langsung merupakan kendala bagi tercapainya tujuan pendidikan umat itu sendiri. Permasalahan tersebut antara lain meliputi :

Aspek Perencanaan

1. Agama cenderung hanya dipelajari secara rasional teoritik saja, sehingga agama lebih sebagai ilmu daripada tuntunan atau pandangan hidup yang membuahkan pemikiran, perilaku dan akhlaq yang Islami.

2. Ilmu agama mengalami stagnasi perkembangan dan sejalan dengan itu para ahli di bidang inipun semakin menyusut, baik kualitatif maupun kuantitatif.

3. Pandangan sebagian besar umat tentang Islam masih bersifat dikotomik atau bahkan sekularistik.

4. Strategi pengembangan pendidikan umat kurang diorientasikan pada pemecahan problem yang dihadapi umat di masa mendatang, tetapi lebih berorientasi pada masa lalu.

Aspek Perangkat Lunak

1. Tujuan pendidikannya kebanyakan tidak terperinci atau terlalu umum, sehingga tidak dapat dijadikan sebagai alat evaluasi. Di samping itu juga, tujuannya kurang diorientasikan pada acuan problematis umat. 
2. Banyak lembaga pendidikan madrasah dan sekolah Islam mengalami "kriris kepemimpinan" dan "krisis kebijakan" karena perkembangannya lebih banyak dipengaruhi oleh variabel luar.

3. Masjid, usroh, majelis-majelis ta'lim (pengajian) tidak mempunyai program yang utuh dan terencana sebagai lembaga pendidikan umat dan bahkan cenderung bersifat sporadis dan simplisistik. Proses pendidikannya lebih bersifat individual daripada sifat ummatik dan behavioral.33

Dalam dataran realitas, permasalahan paling pokok dan substansial yang dihadapi madrasah dan hal ini boleh dianggap sebagai kelemahan mendasar madrasah ialah ketidakmampuan madrasah mengimbangi dinamika kebutuhan masyarakat akan kualitas pendidikan yang semakin tinggi serta dinamika pendidikan pada umumnya, di mana kondisi tersebut diperparah oleh kebijakan pemerintah sendiri yang masih menganggap madrasah sebagai 'anak tiri' dan diperlakukan sebagai sekolah kelas dua. Akibatnya, apresiasi masyarakat terhadap madrasah umumnya kurang menggembirakan dan memandang madrasah sebagai pilihan kedua. Kurang tertariknya masyarakat untuk memilih lembaga-lembaga pendidikan Islam, sebenarnya bukan karena telah terjadi pergeseran nilai atau ikatan keagamaannya yang mulai memudar, melainkan karena sebagian besar lembaga-lembaga tersebut kurang menjanjikan masa depan dan kurang responsif terhadap tuntutan dan permintaan saai ini maupun mendatang. Padahal, paling tidak ada 3 hal yang menjadi pertimbangan masyarakat dalam memilih lembaga pendidikan, yaitu nilai (agama), status sosial dan cita-cita. Masyarakat yang terpelajar akan semakin beragam pertimbangannya dalam memilih pendidikan bagi anak-anaknya.

Ketidakmampuan madrasah dalam mengimbangi dinamika kebutuhan masyarakat menurut beberapa pakar pendidikan Islam disebabkan oleh manajemen/pengelolaan sistem pendidikan yang tidak profesional, terlebih pada aspek perencanaan, penyiapan tenaga pengajar, kurikulum dan pelaksanaan pendidikan Islam itu sendiri. Akibat pengelolaan yang tidak profesional itu, lembaga pendidikan Islam (madrasah) sering kalah bersaing dengan sub sistem pendidikan nasional yang diselenggarakan kelompok-kelompok masyarakat lain.

\footnotetext{
${ }^{33}$ Zaskia, "Beberapa kelemahan mendasar madrasah", izaskia.wordpress.com/.../beberapakelemahan-mendasar-madrasah-1/ - dalam Google.com 11 Januari 2013, 11.23 pm
} 
Bukan rahasia, bahwa citra dan gengsi lembaga pendidikan Islam sering dipandang lebih rendah dibandingkan dengan sistem pendidikan yang diselenggarakan pihak-pihak lain. Dalam kaitan ini, -seperti yang diungkapkan Azyumardi Azra- kita tidak bisa menyalahkan orang tua muslim yang menyerahkan anak-anak mereka ke lembaga pendidikan lain tersebut, selama semua pihak yang terlibat dalam sistem pendidikan Islam tidak berikhtiar secara serius, sistematis dan komprehensif dan programatis membenahi dan mengembangkan sistem pendidikan Islam itu sendiri.

\section{Madrasah dan Aplikasi pada Manajemen Mutu}

Madrasah sebagai lembaga pendidikan, oleh karena manajemen, mutu didasarkan kepada nilai-nilai universal yaitu agama tentunya akan memberikan andil yang tinggi terhadap pengelolaan mutu di madrasah. Madrasah sebagai lembaga pendidikan tentunya memiliki nilai yang sama dengan posisi yang setara dengan lembaga pendidikan lainnya dalam menghasilkan sumber daya manusia Indonesia, tidak bisa dipandang sebelah mata sebagai lembaga kelas dua di negeri ini. Madrasah adalah lembaga pendidikan yang berkelas dan memiliki kekhasan yang memungkinkan dapat melahirkan manusia yang bermutu melalui layanan yang bermutu. Hal ini diakui Nanang Fattah, bahwa mutu pendidikan mencakup 5 hal pokok yaitu:

1. Quality learners (healthy and ready-to-learn children), yaitu siswa sudah memenuhi tingkat kebutuhan minimal agar siap belajar disekolah. Kebutuhan dasar siswa dapat mencakup aspek kesehatan dasar dan transportasi sekolah.

2. Quality learning environments (conducive classrooms), yaitu sekolah memiliki gedung dan atau kelas yang mendukung proses belajar-mengajar sehingga memenuhi standar bangunan minimal.

3. Quality contents (appropriate curriculum relevant to children's lives), yaitu kurikulum sesuai dengan kebutuhan masa depan anak agar dapat mandiri dan menjadi bagian masyarakat secara bertanggung jawab di masa depan.

4. Quality processes (child-centred pedagogy and active learning of childrens), yaitu proses pengajaran sesuai secara faedagogis dan bersifat belajar aktif sehingga memberikan motivasi belajar yang tinggi pada anak. 
5. Quality outcomes (pupils meet established learning standards), yaitu hasil mutu pendidikan memenuhi standar mutu yang sudah ditetapkan sebelumnya. ${ }^{34}$

Secara umum, mutu adalah gambaran dan karakteristik menyeluruh dari barang atau jasa yang menunjukkan kemampuannya dalam memuaskan kebutuhan yang diharapkan atau yang tersirat. Dalam konteks pendidikan, pengertian mutu mencakup input, proses, dan output pendidikan. ${ }^{35}$ Adapun prinsip-prinsip mutu pendidikan sebagai berikut:

\section{Fokus pada pelanggan (peserta didik)}

Dalam dunia pendidikan focus pada pelanggan ini merupakan fokus pada siswa, karena siswa merupakan obyek yang utama dan pertama dalam proses pendidikan, yang ini ini lebih dititik beratkan pada proses pendidikan dari pada hasil pendidikan, karenanya fokus pada siswa dalam proses belajar mengajar ini merupakan hal yang sangat urgen dalam mencapai mutu. Pelanggan disini tidak terfokus pada pelanggan internal saja akan tetapi juga pada pelanggan eksternal, yang mana keduanya sangat penting dalam membangun mutu dan kualitas pendidikan kita, kemudian yang termasuk pelanggan ekternal ini juga orang tua, pemerintah, institusi lembaga swasta (LSM), dan lembagalembaga lain yang mendukung terwujudnya mutu pendidikan yang unggul

\section{Perbaikan Proses}

Konsep perbaikan terus menerus dibentuk berdasarkan pada premisi suatu seri (urutan) langkah-langkah kegiatan yang berkaitan dengan menghasilkan output seperti produk berupa barang dan jasa. Perhatian secara terus menerus bagi setiap langkah dalam proses kerja sangat penting untuk mengurangi keragaman dari output dan memperbaiki keandalan. Tujuan pertama perbaikan secara terus menerus ialah proses yang handal, sedangkan tujuan perbaikan proses ialah merancang kembali proses tersebut untuk output yang lebih dapat memenuhi kebutuhan pelanggan, agar pelanggan puas.

\section{Keterlibatan total}

Pendekatan ini dimulai dengan kepemimpinan manajemen senior yang aktif dan mencakup usaha yang memanfaatkan bakat semua karyawan dalam suatu organisasi untuk mencapai suatu keunggulan kompetitif (competitive advantage) di pasar yang dimasuki.

${ }^{34}$ Lihat Nanang Fattah, Standar Pembiayaan Pendidikan, Bandung, Remaja Rosdakarya, 2012, h. 61-62

${ }^{35}$ www.dikdasmen.depdiknas.go.id, : h. 7-8 diakses tanggal 7 Januari 2012 
Guru dan karyawan pada semua tingkatan diberi wewenang/kuasa untuk memperbaiki output melalui kerjasama dalam struktur kerja baru yang luwes (fleksibel) untuk memecahkan persoalan, memperbaiki proses dan memuaskan pelanggan. Pemasok juga dilibatkan dan dari waktu ke waktu menjadi mitra melalui kerjasama dengan para karyawan yang telah diberi wewenang/kuasa yang dapat menguntungkan. ${ }^{36}$

Sehubungan dengan itu, institusi madrasah sedikitnya terdapat 6 hal yang bisa di identifikasi atau diperhatikan dalam penyiapan konsep madrasah berbasis manajemen (MBM):

a. Pemilihan kepala madrasah dan pendidik profesional

b. Bentuk partisipasi masyarakat dan orang tua (komite madrasah)

c. Pendanaan madrasah

d. Kualitas pembelajaran dan lulusan madrasah

e. Keterlibatan stakeholders pendidikan

f. Political will pemerintah pada berbagai lapisan. 37

Ada beberapa hal yang dapat dilihat mengenai mutu dalam makalah yang berjudul Defening Quality in Education oleh UNICEF tahun 2000, menjelaskan ada beberapa mutu yang dilihat dalam menentukan mutu pendidikanyang antara lain: ${ }^{38}$

\section{Mutu Murid}

Murid yang bermutu harus memiliki:

- Kualitas kesehatan dan gizi yang baik.

- Phisikologis dan sosial yang baik yang diperhatikan dan dikembangkan semenjak dari usia dini.

- Khadiran dalam Pembelajar reguler.

- Dukungan keluarga dalam belajar.

\section{Lingkungan Pembelajaran Bermutu}

1. Elemen Fisik

${ }^{36}$ Lihat Artikel Bulletin Pengawasan No 13\&14 Tahun 1998, http: www.google.co.id diakses tanggal 7 Januari

${ }^{37}$ Mulyasa, Pedoman Manajemen Berbasis Madrasah, (Jakarta: Direktorat Jendral Kelembagaan Agama Islam), hal. 13-14

${ }^{38}$ Lihat makalah"Defening Quality in Education oleh UNICEF tahun 2000, h. 7-20 

a. Fasilitas yang bemutu
b. Interaksi antara insfrastuktur sekolah dan dengan dimensi penjaminan mutu lainya.
c. Luas Kelas

2. Elemen Phisikologi
a. Lingkungan yang aman dan nyaman, khusunya untuk murid perempuan.
b. Kebiasaan guru yang mempengaruhi aman terhadap siswa.
c. Disiplin kebijakan yang efektif
d. Lingkungan yang ramah

3. Pelayanan yang baik

a. Mempunyai prioritas terhadap pelayanan kesehatan.

\section{Mutu Konten}

1. siswa sebagai fakus utama pembelajaran, dan tanpa diskriminasi, merupakan fokus dan standar dari struktur kurikulum sekolah.

2. keunikan lokal dan konten nasional.

3. Materi Bahasa

4. Materi Berhitung

5. Materi Kempampuan Hidup (life skill).

6. Pendidikan tentang Perdamaian.

7. Tantangan dalam mengingkatkan mutu penguasaan pelajaran dalam jumlah siswa yang banyak.

Dengan melihat mutu pendidikan di atas maka, strategi perencanaan pengembangan madrasah secara singkat dapat dikemukakan bahwa permasalahan yang dihadapi dalam pengembangan madrasah adalah lembaga pengelola kurang fungsional, organisasi kelembagaan kurang lengkap, sarana dan prasarana pendidikan belum memenuhi standar, kebanyakan kepemilikan oleh swasta dengan implikasinya sistem akreditasi yang belum mapan, penyebaran madrasah belum merata pada setiap komunitas umat Islam, jumlah guru kurang memadai, penempatan guru tidak merata, kualitas 
mengajar guru masih rendah, keahlian guru tidak sesuai, tenaga administrasi jumlahnya terbatas.39

Mengingat banyaknya jumlah persoalan yang dihadapi dalam pengembangan madrasah secara nasional yang jelas dan memiliki komitmen tinggi terhadap aspirasi yang terus berkembang dan berubah secara sangat cepat. Karena itu disamping kejelasan rancangan, rencana pengembangan juga harus lentur terhadap kemungkinan perubahan situasi dan kondisi. Dalam kaitan ini, kearifan rekayasa bagi kegiatan yang tepat sasaran, merupakan persyaratan personil yang terlibat dalam menejemen baik pada tingkat nasional maupun regional. Untuk maksud tersebut dikemukakan beberapa hal yang menjadi dasar strategi pengembangan madrasah:

1. Menjadikan ajaran agama Islam sebagai basic references seluruh kegiatan pengembangan pendidikan di madrasah. Ajaran Islam merupakan fondasi dari seluruh aktivitas kehidupan manusia muslim, karena itu proporsional manakala setiap kegiatan pendidikan di madrasah memakai rujukan utama Al-Qur'an, baik pada tingkat literal maupun konseptual. Hal ini penting lantaran hasil pengembangan kehidupan masyarakat yang Islami. Dalam tataran yang lebih makro, pendidikan di madrasah harus menghasilkan lulusan yang memiliki kedudukan sentral dalam memberi warna kehidupan masyarakat sekitarnya. Bertolak dari cara pandang ini maka pembangunan madrasah di Indonesia harus mengacu kepada ajaran Islam dalam berbagai segi dan kegiatannya. Pada dataran manajemen madrasah tingkat nasional hal ini bermula dari perencanaan pengembangan sejalan sejalan penyusunan falsafah dasar sampai terakhir dalam bentuk rencana detail pengembangan tiap komponen pembangunan madrasah. Sementara pada dataran tingkat lokal, warna seluruh implementasinya terletak sejakperencanaan pembuatan kurikulum, rekrutmen murid dan guru, proses belajar mengajar kepada pelepasan anak didik dan penarikan sumber daya pendidik dari aktivitas pendidikan.40[14]

2. Madrasah sebagai lembaga pendidikan umum yang beciri khas agama Islam, berfungsi sebagai pengembang dasar-dasar keterampilan multidimensi. Hal ini

\footnotetext{
${ }^{39}$ Abdul Rachman Shaleh, Pendidikan Agama dan Keagamaan, (Jakarta: PT Gemawindu Pancaperkasa, 2000), hal. 127.

${ }^{40}$ Abdul Rachman Shaleh, Pendidikan Agama dan Keagamaan, hal. 128-129
} 
lantaran pendidikan pada madrasah pada dasarnya merupakan subsistem dari pendidikan umum yang sederajat. Pendidikan pada madrasah memiliki fungsi yang sama dengan pendidikan umum lainnya yakni untuk mengembangkan kemampuan serta meningkatkan mutu kehidupan dan martabat manusia Indonesia dalam rangka upaya mewujudkan tujuan nasional. Demikian juga halnya dengan tujuan pada pendidikan madrasah. Ia terikat pada tujuan pendidikan nasional yakni "mencerdaskan kehidupan bangsa dan mengembangkan manusia Indonesia seutuhnya yaitu manusia yang beriman dan bertakwa terhadap Tuhan Yang Maha Esa dan berbudi luhur, memiliki pengetahuan dan keterampilan, kesehatan jasmani dan rohani, kepribadian yang mantap dan mandiri serta tanggung jawab kemasyarakatan dan kebangsaan." Sejalan dengan semakin terdiversifikasi jenisjenis keterampilan pembangunan yang diperlukan, maka pengembangan dasardasar keilmuan dan penguasaan keterampilan profesional tingkat menengah pun (dalam hal ini pendidikan di madrasah) perlu pengembangan ke segala sektor kehidupan. Sudah barang tentu hal ini dengan memperhitungkan kondisi daerah, kecenderungan penyediaan sumber daya alam, keterbukaan peluang sektor-sektor profesi kehidupan serta ketersediaan sumber daya manusianya.41[15]

3. Pengembangan secara bertahap. Pengembangan madrasah baik negeri maupun swasta ke arah yang menjadi visi rencana pengembangan harus dilakukan secara bertahap. Pentahapan dalam pengembangan dimaksudkan supaya dalam kegiatankegiatan yang sifatnya ad-hock terhindari, sebab kegiatan demikian akan mengakibatkan program antar periode jabatan pejabat jadi tidak dalam satu kesatuan yang menyeluruh. Sehingga pengembangan tidak pernah selesai dan diketahui hasilnya secara jelas.

Melalui pengembangan secara bertahap, kompleksitas permasalahan dapat dikurangi serta berbagai intervensi atas kegiatan pembinaan, lantaran aspirasi yang berubah terlalu cepat dan meloncat-loncat. Dengan melihat permasalahan tersebut di atas dapat diketahui bahwa dalam pengembangan madrasah secara nasional sangat diperlukan antara lain adanya peningkatan keterampilan manajemen dan kesadaran fungsi masingmasing bagian pengelola madrasah secara keseluruhan, diperlukan pengadaan dan

\footnotetext{
${ }^{41}$ Abdul Rachman Shaleh, Pendidikan Agama dan Keagamaan, hal.129
} 
penyempurnaan sarana dan prasarana pendidikan baik fasilitas fisik maupun fasilitas non fisik (seperti perangkat supervisi guru), pengadaan dan peningkatan mutu staf pengajar, pengadaan dan peningkatan mutu staf tata usaha, rangsangan kegiatan siswa serta pembinaan lulusan-lulusan. Dengan melihat permasalahan di atas maka tahapan-tahapan pengembangan madrasah setidaknya memerlukan empat tahapan yaitu:

a. Pemerataan kesadaran dan keterampilan manajemen pada tingkat pengelola dan pelaksanaan madrasah.

b. Pengembangan sarana dan prasarana pendidikan madrasah

c. Pengadaan dan peningkatan mutu staf pengajar

d. Pengadaan dan peningkatan mutu staf tata usaha.42

Namun demikian Pada dataran praksisnya, eksistensi madrasah seringkali menghadapi pilihan yang sulit, yaitu antara kebutuhan keagamaan dan kebutuhan duniawi. Di satu sisi, madrasah dituntut bisa berfungsi meningkatkan pemahaman ilmu-ilmu agama dan kemampuan mengamalkan ajaran Islam. Sementara di sisi lain lembaga ini dituntut berfungsi menumbuhkan kemampuan peserta didik dalam memenuhi kebutuhan hidup yang tidak seluruhnya bisa dipecahkan dengan ilmu agama.Dengan mengemban dua tujuan sekaligus di atas, membuat pelaku manajemen madrasah jauh lebih berat dibandingkan dengan sekolah. Sehingga berbicara tentang pemberdayaan mutu madrasah harus dimulai dari manajemennya terlebih dahulu. ${ }^{43}$

Dalam pengalokasian anggaran misalnya, madrasah dalam naungan Depag hanya dipatok 6,9 triliun, termasuk untuk gaji gurunya, sedangkan anggaran pendidikan di Depdiknas sampai puluhan triliun, dan masih ditambah lagi dengan alokasi dari APBD di daerah-daerah.Padahal, berdasarkan catatan pemerintah dari segi kuantitas madrasah dari tingkat Ibtidaiyah hingga Aliyah saat ini hampir mencapai 39 ribu buah. Secara kuantitas, jumlah siswa madrasah dengan berbagai tingkatan tersebut diperkirakan mencapai 500 ribu.Menurut catatan Departemen Agama (yang sekarang berubah menjadi Kementerian Agama) tahun 2005, bahwa jumlah madrasah aliyah tercatat 3.772 unit, terdiri atas 577 $(15,3 \%)$ berstatus negeri dan $3.195(84,7 \%)$ berstatus swasta. Jumlah madrasah tsanawiyah di seluruh Indonesia sebanyak 10.792, meliputi 9.624 (89,2\%) madrasah swasta dan hanya

\footnotetext{
${ }^{42}$ Abdul Rachman Shaleh, Pendidikan Agama dan Keagamaan, hal.130

${ }^{43} \mathrm{http}: / /$ mujtahid-komunitaspendidikan.blogspot.com/2010/05/upaya-membenahi-mutumadrasah.html diakses tanggal 7 Januari 2013.
} 
49,7\% yang baru terakreditasi. Sementara madrasah ibtidaiyah (MI) berjumlah 22.799, meliputi 1.482 (6,5\%) negeri dan $21.317(93,5 \%)$ berstatus swasta.

Dari keseluruhan MI swasta yang baru terakreditasi 59 buah, sisanya 8.730 (41\%) berstatus terdaftar atau belum terdaftar. Bila dipahami secara mendasar bahwa data di atas menunjukkan kualitas madrasah masih di bawah standar rata-rata. Ini artinya madrasah masih menghadapi persoalan yang perlu mendapat perhatian serius, terutama pemerintah dan praktisi pendidikan. Khozin dalam "Manajemen Pemberdayaan Madrasah" (2006) menawarkan sebuah inisiatif baru bagaimana mencari sebuah peluang-peluang agar mutu atau kualitas madrasah tetap eksis dan berusaha keluar dari kebelengguan yang mematikan itu. Pemberdayaan harus dimaknai dan diawali dengan tekad dan semangat oleh semua elemen yang berkecimpung di madrasah. Setiap pendidik dituntut agar melakukan inovasi yang relevan dengan visi dan misi madrasah untuk meningkatkan kualitas madrasah. ${ }^{44}$

Namun problem kualitas menjadi perhatian dalam memotret madrasah sebagian banyak madrasah, jika dilihat dari hasil Nilai Ujian Nasional masih rendah, apalagi bila dibandingkan dengan sekolah umum pada umumnya. Kecuali beberapa madrasah yang ditangani secara khusus, ternyata juga berhasil unggul dan dapat meraih prestasi lebih tinggi bilamana dibandingkan dengan prestasi sekolah umum. Tetapi madrasah yang berhasil berprestasi seperti ini masih terbatas jumlahnya. Sebut saja misalnya, sebagai conoh Madrasah Terpadu Malang, yaitu Madrasah Ibtidaiyah Negeri, Madrasah Tsanawiyah Negeri dan Madrasah Aliyah Negeri Malang, prestasi akadmiknya setiap tahun selalu unggul dan dapat bersaing dengan lembaga pendidikan pada ummnya.Membandingkan madrasah dengan sekolah umum, yang hanya dilihat dari hasil Ujian Nasional sesungguhnya tidaklah adil. Kedua jenis lembaga pendidikan ini sesungguhnya menyandang visi dan misi dan kondisi yang agak berbeda. Visi, misi dan kondisi yang berbeda tentu berimplikasi pada beban belajar dan perangkat pendukung yang berbeda pula. Tetapi anehnya, sebagian masyarakat menuntut hasil yang sama hanya dari sebagian prestasi yang dihasilkan, katakanlah hasil UN nya. Padahal keduanya sesungguhnya tidaklah sama. Sekolah umum, pada umumnya berstatus negeri. Dengan statusnya itu lembaga pendidikan pemerintah ini segala sesuatunya tercukupi sekalipun

\footnotetext{
${ }^{44} \mathrm{http} / /$ mujtahid-komunitaspendidikan.blogspot.com/2010/05/upaya-embenahi-mutuadrasah.html diakses tanggal 7 Januari 2013.
} 
dalam batas-batas`minimal, misalnya guru, perpustakaan, laboratorium dan sarana pendidikan lainnya. ${ }^{45}$

Oleh karena itu, Jomtien dan Dakar menjelaskan bahwa kualitas adalah memperkenalkan yang diinginkan karakteristik dari pelajar (kesehatan, motivasi pelajar), proses (guru yang kompeten menggunakan pedagogi aktif), isi (kurikulum yang relevan), dan sistem (penguasaan yang bagus dan alokasi sumber daya yang tepat). ${ }^{46}$ Dalam konsep UNESCO konsep dari kualitas adalah UNESCO melihat pendidikan sepanjang hidup berawal dari empat tiang:

1. Belajar untuk mengetahui pengetahuan, bahwa pelajar membangun pengetahuan sehari-hari mereka, menggabungkan keaslian dan elemen luar.

2. Belajar untuk focus kepada aplikasi praktis apa yang telah dipelajari.

3. Belajar untuk hidup bersama, bebas dari diskriminasi, mendapat peluang yang sama keluarga dan komunitas.

4. Belajar untuk menekankan kemampuan yang dibutuhkan untuk individu untuk mengembangkan seluruh potensi mereka. ${ }^{47}$

Dalam peningkatas kualitas UNICEF melakukan pendekatan lima dimensi kualitas dalam pengakuan pendidikan, yaitu: pelajar, lingkungan, isi, proses, dan hasil, didirikan pada menjunjung keseluruhan anak, dan anak-anak, untuk kelangsungan hidup, perlindungan, pengembangan dan pertisipasi. ${ }^{48}$ Oleh karena itu, ada macam kualitas antara lain:

1. Kualitas dalam tradisi masyarakat

Menstandarisasi, menentukan, menggambarkan secara eksternal atau kontrol kurikulum menolak. Mereka melihat bahwa segala kemungkinan pengaruh untuk pelajar untuk memperbaiki pengertian mereka dan untuk program pendidikan merespon ke masing-masing pelajar keadaan dan diperlukan. Peranan nilai untuk memberi pelajar informasi dan penilaian tentang kualitas pendidikan mereka masing-masing.

\footnotetext{
${ }^{45} \mathrm{http}: / /$ staisukabumi.blogspot.com/2009/11/problem-peningkatan-mutu-madrasah.html diakses tanggal 10 Januari 2013

${ }^{46}$ Lihat "Understanding Education Quality, dalam EFA Global Monitoring Refort Chapter 1, tahun, 2000, h. 29

${ }^{47}$ Lihat "Understanding Education Quality, dalam EFA Global Monitoring Refort Chapter 1, tahun, 2000, h. 30

${ }^{48}$ Lihat UNICEF 2000
} 
- Peranan guru adalah sebagai fasilitator daripada instructor.

- Membangun lingkungan, sementara menerima pengajaran, penekanan

2. Kualitas dalam tradisi tingkah laku

- Standarisasi, menggambarkan eksternal dan control kurikulum, dasar menentukan objektivitas dan menentukan kebebasan kepada pelajar.

3. Kualitas dalam tradisi kritis

- Bahwa pendidikan merubah masyarakat dengan cepat;

- Kurikulum dan metode pengajaran adalah semangat analisis kritis dari hubungan kekuatan social dan jalan dalam pengetahuan formal adalah menghasikan dan menyebarkan.

- Partisipasi aktif oleh pelajar dalam desain pembelajaran pengalaman (ekperien).

4. Kualitas dalam tradisi asli.

- Mendekati tendensi dari Eropa tidak sesuai dalam masyarakat yang beragam dan keadaan ekonomi.

- Relevansi meyakinkan menggambarkan local desain dari isi kurikulum, pedagogi dan penilaian.

- Semua pelajar perlu memperkaya pengetahuan adalah prioritas pengetahuan, mengakumulasi berbagai eksperimen .

- Pelajar harus memainkan peranan dalam menggambarkan kurikulum mereka.

- Pelajar harus melewati batas dari sekolahan melalui non formal dan aktifitas pembelajaran yang kekal. ${ }^{49}$

Strategi Manajemen Berbasis Madrasah untuk perbaikan mutu pendidikan madrasah, maka strateginya sebagai berikut:

1. Penyiapan Konsep

${ }^{49}$ Lihat "Understanding Education Quality, dalam EFA Global Monitoring Refort Chapter 1, tahun, 2000, h. 32-35 
Banyak faktor yang berpengaruh terhadap keberhasilan MBM, misalnya tingkat ekonomi masyarakat, sosial budaya, politik dan taraf pendidikan masyarakat, kebijakan pemerintah, organisasi, kepemimpinan kepala madrasah, strategi pembelajaran, dan profesionalisme tenaga pendidikan. Kesemuanya itu merupakan komponen yang perlu diperhatikan dalam konteks MBM.

2. Pengelompokan madrasah

Perbedaan kemampuan manajemen menuntut perlakuan yang berbeda terhadap setiap madrasah sesuai dengan tingkat kemampuan masing-masing dalam menyerap paradigma baru yang ditaawarkan. Misalnya suatu madrasah mungkin hanya memerlukan pelatihan dalam melaksanakan MBM, tetapi mungkin madrasah memerlukan dukungan lain dari pemerintah agar dapat menerapkan paradigma baru tersebut. Dengan mempertimbangkan kemampuan, kewajiban, dan kewenangan madrasah terhadap pelaksanaan MBM, dapat dibedakan antara satu madrasah dengan yang lain. Dalam hal ini Departemen Agama dan jajarannya perlu melakukan berbagai upaya bagi pengembangan madrasah yang kurang memiliki kemampuan manajemen dalam mempersiapkan implementasi MBM, termasuk masalah pendanaan, pengadaan fasilitas, dan sumber belajar.50

3. Pentahapan implementasi MBM

Implementasi MBM secara menyeluruh sebagai realisasi desentralisasi pendidikan memerlukan perubahan-perubahan mendasar terhadap aspek-aspek yang menyangkut keuangan, ketenagaan, kurikulum, sarana dan prasarana, serta partisipasi masyarakat. Mengingat kompleksnya permasalan pendidikan di madrasah, MBM perlu dilaksanakan secara bertahap, paling tidak melalui tiga tahap: yaitu jangka pendek (tahun pertama sampai dengan tahun ketiga), jangka menengah (tahun keempat sampai tahun keenam), dan jangka pangjang setelah tahun keenaam.

Untuk implementasi MBM sendiri maka diperlukan empat tahapan yaitu:

a. Tahap sosialisasi. Tahap ini merupakan tahap yang penting mengingat luasnya wilayah nusantara terutama daerah-daerah yang sulit dijangkau oleh media informasi, baik cetak maupun elektronik.

\footnotetext{
${ }^{50}$ Abdul Rachman Shaleh, Pendidikan Agama dan Keagamaan, hal.14
} 
b. Tahap piloting. Tahap ini merupakan tahap uji coba agar penerapan konsep menejemen berbasis madrasah tidak mengandung resiko.

c. Tahapan pelaksanaan. Tahap ini merupakan tahap untuk melakukan berbagai diskusi, curah pendapat dan lokakarya mini antar kelompok kerja MBM dengan berbagai unsur terkait, yakni guru, kepala madrasah, pengawas, tokoh agama, pengusaha, dan para akademisi.

d. Tahap diseminasi. Tahap ini merupakan tahap memasyarakatkan model MBM yang telah diujicobakan ke berbagai madrasah baik negeri maupun swasta, agar seluruh madrasah dapat mengimplementasikan MBM secara efektif dan efisien, sesuai dengan kondisinya masing-masing. 51

Sehubungan dengan itu, Menurut Imron Arifin, unsur pendukung madrasah unggul itu setidaknya ada sembilan faktor, yaitu:

1. Faktor sarana dan prasarana. Meliputi

(a) fasilitas sekolah yang lengkap dan memadahi,

(b) sumber belajar yang memadahi dan

(c) sarana penunjang belajar yang memadahi.

2. Faktor guru. Meliputi

(a) tenaga guru mempunyai kualifikasi memadahi,

(b) kesejahteraan guru terpenuhi,

(c) rasio guru-murid ideal,

(d) loyalitas dan komitmen tinggi, dan

(e) motivasi dan semangat kerja guru tinggi.

3. Faktor murid. Meliputi

(a) pembelajaran yang terdiferensiasi,

(b) kegiatan intra dan ekstrakulikuler bervariasi,

(c) motivasi dan semangat belajar tinggi,

(d) pemberdayaan belajar bermakna.

4. Faktor tatanan organisasi dan mekanisme kerja. Meliputi

(a) tatanan organisasi yang rasional dan relevan,

(b) program organisasi yang rasional dan relevan,

\footnotetext{
${ }^{51}$ Abdul Rachman Shaleh, Pendidikan Agama dan Keagamaan, hal.17-18
} 
(c) mekanisme kerja yang jelas dan terorganisasi secara tepat.

5. Faktor kemitraan. Meliputi

(a) kepercayaan dan harapan orangtua tinggi,

(b) dukungan dan peran serta masyarakat tinggi,

(c) dukungan dan bantuan pemerintah tinggi.

6. Faktor komitmen/sistem nilai. Meliputi

(a) budaya lokal yang saling mendukung,

(b) nilai-nilai agama yang memicu timbulnya dukungan positif.

7. Faktor motivasi, iklim kerja, dan semangat kerja. Meliputi

(a) motivasi berprestasi pada semua komunitas sekolah,

(b) suasana, iklim kerja dan iklim belajar sehat dan positif, dan

(c) semangat kerja dan berprestasi tinggi.

8. Faktor keterlibatan Wakil Kepala sekolah dan guru-guru. Meliputi

(a) keterwakilan kepala sekolah dalam pembuatan kebijakan dan pengimplementasiannya,

(b) keterwakilan kepala sekolah dan guru-guru dalam menyusun kurikulum dan program-program sekolah, dan

(c) keterlibatan wakil kepala sekolah dan guru-guru dalam perbaikan dan inovasi pembelajaran.

9. Faktor kepemimpinan kepala sekolah. Meliputi

(a) piawai memanfaatkan nilai religio-kultural,

(b) piawai mengkomunikasikan visi, inisiatif, dan kreativitas,

(c) piawai menimbulkan motivasi dan membangkitkan semangat,

(d) piawai memperbaiki pembelajaran yang terdiferensiasi,

(e) piawai menjadi pelopor dan teladan, dan

(f) paiwai mengelola administrasi sekolah.

Selain dari pandangan di atas, penulis ingin menjelaskan dan barangkali menambahkan beberapa unsur pendukung utama yang harus dimiliki oleh madrasah unggulan. Paling tidak, ada tiga hal yang perlu tersedia, yaitu (1) sumber daya manusia unggul, (2) sarana 
prasarana akademik yang representatif, dan (3) fasilitas penunjang internalisasi nilai keislaman.52 Hal ini sangat sejalan dengan proses mutu meliputi:

Proses mutu meliputi:

1. Guru

a. Pendidikan Profesional bagi guru

b. Kopetensi guru dan effesiensi sekolah

c. Pengembangan profesionalime yang berkelanjutan

d. Dukungan yang berkelanjutan terhadap siswa sebagai fokus utama pendidikan.

e. Aktif, Standar yang berlandaskan metode partisipasi.

f. Mekanisme Evaluasi Guru

g. Keyakinan guru bahwa setiap siswa mampu belajar.

h. Kondisi Kerja Guru

2. Sepervisi dan dukungan

a. Kukungan Administratif dan Kepemimpinan.

b. Akses Siswa terhadap bahasa yang digunakan di sekolah

c. Menggunakan teknologi untuuk mengurangi dari pada meningkatkan perbedaan.

d. Proses dan fasilitas yang berbeda.

\section{Mutu Lulusan}

a. Capaian dari Kemampuan Berbahasa dan Berhitung.

b. Menggunakan Ujian Formatif untuk meningkatkan capaian lulusan.

c. Lulusan diterima dengan baik olah orang tua.

d. Lulusan mempunyai kemampuan untuk berpartisipasi dalam komunitas, kepercayaan diri, dan menjadi pembelajar seumur hidup.

e. Mempunyai Capaian Pengalaman untuk mengarahkan kecendrungan lulusan.

f. Kesehatan Lulusan dan Lulusan Berkemampuan hidup. ${ }^{53}$

Oleh karena institusi madrasah pada konteks total quality management (TQM) atau manajemen mutu terpadu (MMT), mendefinisikan mutu atau kualitas memerlukan pandangan komprehensif, karena terdapat sejumlah elemen agar sesuatu hal dikatakan bermutu atau

52 Mujtahid, "Perencanaan Madrash dan Sekolah Islam Unggulan”, mujtahidkomunitaspendidikan.blogspot.com/.../perencanaan-madrasah-dan-sekolah-islam.html dalam Google.com. 18 Januari 2011, 11.45 pm

${ }^{53}$ Lihat makalah"Defening Quality in Education oleh UNICEF tahun 2000, h. 7-20 
berkualitas. Elemen dimaksud adalah: (1) kualitas meliputi usaha memenuhi atau melebihi harapan pelanggan; (2) kualitas mencakup produk, jasa, manusia, proses, dan lingkungan; dan (3) kualitas merupakan kondisi yang selalu berubah-dalam arti apa yang dianggap berkualitas saat ini mungkin dianggap kurang berkualitas pada saat yang lain. ${ }^{54}$

TQM atau MMT dapat didefinisikan dari tiga kata yang dimilikinya: total (keseluruhan, terpadu), quality (kualitas, derajat/tingkat keunggulan barang atau jasa), management (tindakan, seni, cara pengendalian, pengarahan). Dari ketiganya TQM didefinisikan sebagai "sistem manajemen yang berorientasi pada kepuasan pelanggan (customer satisfaction) dengan kegiatan yang diupayakan benar sekali (right first time), melalui perbaikan berkesinambungan (continous improvement) dan memotivasi staf/karyawan/orang yang terlibat.

Kualitas atau mutu dalam konteks TQM juga merupakan suatu filosophi dan metodologi yang membantu lembaga untuk mengelola perubahan secara totalitas dan sistemik yang meliputi perubahan paradigma, visi, misi

serta tujuan. Esensinya adalah perubahan kultur, bahwa kualitas adalah ide yang dinamik sebagai konsep yang relatif. Jadi kualitas bukan atribut produk atau jasa saja, melainkan spesifikasi yang digunakan sebagai sarana agar barang atau jasa yang dihasilkan berada di atas standar. ${ }^{55}$

Kualitas atau mutu memiliki dua aspek yaitu, pengukuran berdasar spesifikasi dan berdasarkan pemenuhan kebutuhan atau tuntutan pelanggan. Artinya suatu produk barang atau jasa disebut berkualitas jika pertama, memenuhi spesifikasi dalam tujuan pembuatan atau pelayanannya (quality in fact) dan kedua, jika memenuhi selera dan kebutuhan pelanggan sehingga meningkatkan keinginan, minat dan kebutuhan mereka (quality in perception). ${ }^{56}$

Sejalan dengan hal di atas, pada mulanya TQM juga dipahami sebagai "perpaduan semua fungsi dari perusahaan/institusi ke dalam falsafah holistik yang dibangun berdasarkan konsep kualitas, teamwork, produktivitas, dan pengertian serta kepuasan pelanggan".

\footnotetext{
${ }^{54}$ Fandy Tjiptono\&Anastasia Diana Total quality management (TQM).Yogyakarta: Penerbit And,2003, h. 3-4

${ }^{55}$ Abdur Rachman Shaleh, Madrasah dan Pendidikan Anak Bangsa, Visi, Misi dan aksi, h. 157

${ }^{56}$ Abdur Rachman Shaleh, Madrasah dan Pendidikan Anak Bangsa, Visi,Misi dan aksi, h. 160
} 
Selain itu TQM juga dimaknai sebagai "sistem manajemen yang mengangkat kualitas sebagai strategi usaha dan berorientasi pada kepuasan pelanggan dengan melibatkan seluruh anggota organisasi. Dengan demikian TQM menjadi suatu pendekatan dalam menjalankan usaha yang mencoba untuk memaksimumkan daya saing organisasi melalui perbaikan terus menerus atas produk, jasa, manusia, proses, dan lingkungannya. TQM sebagai pendekatan (approach) hanya dapat dicapai dengan memperhatikan sejumah karakteristik: (1) fokus pada pelanggan (internal \& external); (2) memiliki obsesi tinggi terhadap kualitas; (3) menggunakan pendekatan ilmiah dalam pengambilan keputusan dan pemecahan masalah; (4) memiliki komitmen jangka panjang; (5) membutuhkan kerjasama tim (teamwork); (6) memperbaiki proses secara kontinu; (7) menyelenggarakan pendidikan dan pelatihan; (8) memberikan kebebasan yang terkendali; (9) memiliki kesatuan tujuan; dan (10) adanya keterlibatan dan pemberdayaan karyawan. Sedangkan tujuan sistem kualitas atau mutu adalah memberikan keyakinan bahwa produk atau jasa yang dihasilkan (output/keluaran) memenuhi persyaratan mutu pengguna. Sistem mutu tersebut mencakup jaminan mutu dan pengendalian mutu. ${ }^{57}$

TQM tidak bisa lepas dari peran William Edward Deming yang mengangkat teorinya sebagai substitusi scienti-c management yang dipopulerkan oleh Frederic Winslow Taylor, dan menekankan work harder do their best (Bonsting1, 2001: 7). Dalam scienti-c management, sebuah pekerjaan dimulai dengan plan, diikuti dengan do, yakni mengerjakan pekerjaan dalam skala kecil, diikuti dengan study untuk mengkonfirmasikan perencanaan dengan hasil uji lapangan, dimodifikasi sesuai hasil studi untuk digunakan dalam skala yang lebih besar. Teorinya disebut fase $a c t^{58}$. Secara skematik teori Deming dapat digambaran sebagai berikut:

${ }^{57}$ Bambang Hadi Wiardjo dan Sulistijarningsih Wibisono Memasuki pasar internasional dengan ISO 9000, sistem manajemen mutu. Jakarta: Ghalia Indonesia, 1996, h. 4-7

${ }^{58}$ Bonstingl, J.J. Quality of school. California: Corwin Press, 2001, h. 9-10 
(4)

Act

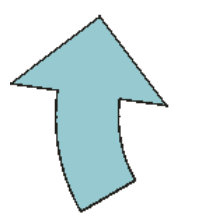

(3)

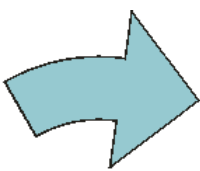

(1)

Plan

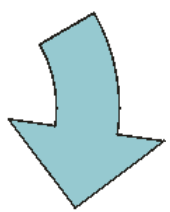

(2)

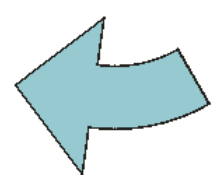

Do

Gambar 1. Lingkaran Deming (Bonstingl, 2001: 10)

Melalui teorinya ini Deming menekankan perbaikan-perbaikan yang tidak pernah henti, dan setiap apa yang dikerjakan selalu diawali dengan perencanaan, dan perencanaan diilhami dengan hasil yang telah tercapai sebelumnya, sehingga ada perbiakanperbaikan untuk implementasi rencana berikutnya. Teori Deming diteruskan Joseph M. Juran. Ia mendefinisikan kualitas adalah "kesesuaian untuk pemakaian", kualitas adalah "terbebas darikesalahan". Juran mengembangkan lingkaran kualitas yang dinamainya dengan "spiral ofprogress in quality" yang meliputi, customer, product development, operating, marketing, further development, dan lain-lain. Proses kualitas itu dimulai dari dan berakhir pada pelanggan. ${ }^{59}$. Dengan teori lingkaran spiral tersebut, Juran sebagimana Deming menekankan perbaikan terus-menerus dalam kualitas.

\section{Memperkuat Mutu Madrasah Menyonsong 4.0}

Perubahan era masyarakat 1.0 merupakan kelompok yang masih mengandalkan dan bergantung pada alam seperti berburu, serta berkumpul bersama dalam satu kelompok. Ilustrasi masyarakat Ilustrasi masyarakat (FREEPIK/peoplecreations) Lalu, masyarakat 2.0 merupakan kelompok yang sudah menerapkan kebiasaan bercocok tanam. Dalam hal kehidupan sosial, kelompok ini sudah mengenal tatanan sosial. Sementara masyarakat 3.0 merupakan kelompok yang sudah mengenal industri untuk mengatasi beberapa masalah seperti produksi massal. Kemudian era 4.0 adalah kelompok masyarakat yang terhubung

${ }^{59}$ Bonstingl, J.J. Quality of school. California: Corwin Press, 2001, 14 
dalam jaringan dan teknologi dan informasi. Sedangkan masyarakat 5.0 merupakan kelompok yang menerapkan teknologi yang berfokus pada kehidupan manusia, berlandaskan pada kebiasaan masyarakat $4.0^{60}$

Madrasah sebagai lembaga pendidikan Islam, harus mampu mengikuti perkembangan zaman dengan menyatukan diri dengan dengan revolusi industri 4.0. mampu mengikuti perkembangan era demi menyongsong Pendidikan Islam 4.0, maka mau tidak mau semua permasalahan laten di atas harus mampu dicarikan jalan keluarnya. Jika tidak, maka sulit-jika enggan berkata mustahil-mewujudkan madrasah yang kontekstual terhadap zaman. Oleh sebab itu, sebagaimana diutarakan di atas, perlu adanya reformasi dan pembaruan terhadap segenap aspek dalam pendidikan madrasah.

Meminjam istilah Rhenald Kasali, ada tiga langkah yang harus dilakukan pendidikan Islam di era $4.0 \mathrm{ini}$, yaitu disruptive mindset, self-driving, dan reshape or create. ${ }^{61}$ Disruptive mindset. Mindset adalah bagaimana manusia berpikir yang ditentukan oleh setting yang kita buat sebelum berpikir dan bertindak. Pendidikan Islam hari ini tengah berada di zaman digital yang serba cepat, moboilitas tinggi, akses informasi menjadi kebutuhan primer setiap orang. Selain itu, masyarakat hari ini menuntut kesegeraan dan real-time. Segala sesuatu yang dibutuhkan harus dengan segera tersedia. Bila akses terhadap kebutuhan itu memakan waktu terlalu lama, maka masyarakat akan meninggalkannya dan beralih ke pelayanan yang lain. Intinya, tuntutan di era disrupsi ini adalah respons.

Kecepatan respons sangat berpengaruh terhadap user. Inilah yang dinamakan Rhenald Kasali sebagai corporate mindset (mindset korporat). Mindset ini perlu dibangun oleh para pelaku pendidikan Islam. Sehingga pelayanan yang diberikan kepada user tidak lagi birokratis. Lebih lanjut Rhenald mengatakan, ciri- ciri orang yang ber-mindset korporat adalah; ${ }^{62}$ pertama, tidak terikat waktu dan tempat. Ia bekerja tidak terbatas pada jam dan ruang kerja. Orang seperti ini telah menyadari bahwa waktu dan tempat tidak lagi

\footnotetext{
${ }^{60}$ Rosiana Haryanti https://properti.kompas.com/read/2019/01/25/213000921/jepangmenjelang-5.0-society-dan-era-menikmati-hidup?page=all.

${ }^{61}$ Lihat Sigit Priatmoko, Memperkuat Ekstensi Pendidikan Islam Era 4.0 dalam jurnal Studi Pendidikan Islam, Ta'lim, Vol. 1 No.2, 2018

${ }^{62}$ Rhenald Kasali, Disruption "Tak Ada yang Tak Bisa Diubah Sebelum Dihadapi Motivasi Saja Tidak Cukup" Menghadapi Lawan-Lawan Tak Kelihatan dalam Peradaban Uber. Jakarta: PT Gramedia Pustaka Utama, 2017, h. 305
} 
menjadi penghalang dalam bekerja. Teknologi telah mematikannya. Manusia hari ini bisa terhubung 24 jam sehari, 7 hari seminggu, tanpa terikat waktu dan tempat. Jika mindset tersebut diterapkan dalam manajemen lembaga pendidikan Islam, maka akan terbentuk sistem manajerial yang efektif dan efisien. Selanjutnya, apabila ditarik dalam konteks pembelajaran, guru akan lebih leluasa dan fleksibel dalam menjalankan tugas dan fungsinya.

Kedua, memberikan pelayanan yang proaktif. Kegiatan pembelajaran yang masih terkonsentrasi pada transfer pengetahuan dari guru dan terkurung di dalam kelas, akan sulit menghasilkan lulusan yang berdaya saing tinggi. Paradigma pendidikan telah berubah, bukan lagi teacher centered, tapi student centered. Guru dituntut untuk lebih proaktif memberikan fasilitas, bimbingan, dan dampingan kepada peserta didik. Ketiga, tidak terpaku pada anggaran biaya. Berbeda dengan mental birokrat yang serba terikat dengan biaya (tidak kerja jika tidak ada anggaran). Orang yang ber-mindset korporat tidak berhenti berinovasi karena kendala uang.

Keempat, memaksimalkan fungsi media sosial. Pengelola madrasah hari ini harus mampu memanfaatkan kemajuan media komunikasi yang tersedia. Media sosial bukan lagi hiburan semata. Ia telah menjelma menjadi alat komunikasi yang efektif, alat bantu kerja, dan inspirasi dalam berinovasi. Peluang ini harus mampu dimanfaatkan dengan baik. Kelima, berpikir solutif jika dihadapkan pada masalah. Bukan sibuk memikirkan alasan untuk menyelematkan diri. Keenam, tidak alergi terhadap perubahan. Justru di era sekarang, perubahan telah menjadi kebutuhan. Suatu lembaga jika tetap bertahan/statis dalam pengelolaannya, akan kalah dengan lembaga yang pengelolaannya lebih dinamis. Dan ketujuh, berpikir dan bertindak strategik. Langkah dalam pengelolaan lembaga pendidikan Islam harus memiliki roadmap yang jelas. Sasaran yang dicanangkan harus realistis. Oleh karena itu, reorientasi kurikulum dan visi pendidikan Islam urgent untuk dilakukan. Kurikulum, visi, program tahunan, program semester harus jelas, fleksibel, kontekstual, dan futuristik.

Self-Driving. Organisasi yang tangkas dan dinamis dalam berdaptasi mengarungi samudra disruption adalah organisasi yang memiliki SDM (Sumber Daya Manusia) bermental pengemudi yang baik (good drivers) bukan penumpang (passanger). ${ }^{27}$ SDM yang bermental good driver akan mau membuka diri, cepat dan tepat membaca situasi, berintegritas, tangkas dalam bertindak, waspada terhadap segala kemungkinan buruk, dan 
mampu bekerja efektif, inovatif, dan efisien. Kemampuan-kemampuan tersebut terutama dibutuhkan oleh para pemimpin dan pengelola lembaga pendidikan Islam. Mereka dituntut untuk dapat menjadi pengemudi yang handal bagi lembaganya. Oleh karenanya, kompetensi manajerial saja tidaklah cukup. Melainkan harus pula diringi dengan kemampuan memimpin. Sementara SDM yang bermental penumpang akan cenderung birokratis, kaku, lambat, dan kurang disiplin.

Reshape or Create. Ada genealogi pemikiran yang populer di kalangan umat Islam yang sampai saat ini masih dipegang teguh. Genealogi tersebut adalah "mempertahankan yang lama yang baik dan mengambil yang baru yang lebih baik". Sebagaimana banyak disinggung di atas, bahwa era 4.0 merupakan era dimana kecepatan dan kemudahan menjadi tuntutan manusia. Hal ini tentu memerlukan penyesuaian masif. Maka ada dua pilihan logis bagi pendidikan Islam untuk menghadapi era ini, yaitu reshape atau create.

Reshape dalam genealogi di atas berarti mempertahankan yang lama yang baik. Akan tetapi, di era 4.0 mempertahankan saja tidak cukup, harus dipertajamCara-cara dan sistem lama yang masih baik dan relevan perlu untuk dimodifikasi sesuai dengan perubahan dan perkembangan zaman. Misalnya pada tataran manajemen dan profesionalitas SDM, maka perlu diperkuat dan ditingkatkan kompetensi dan kapasitasnya. Bisa melalu diklat pelatihan, seminar, loka karya, beasiswa studi, dan sebagainya.

Alternatif lainnya adalah create, menciptakan sesuatu yang sama sekali baru atau dalam genealogi di atas "mengambil yang baru yang lebih baik". Hal ini berarti, cara dan sistem yang lama telah usang (obsolet). Sehingga tidak mungkin dipakai lagi. Jalan keluar satu-satunya adalah membuat cara dan sistem yang sama sekali baru. Misalnya mengembangkan sistem pelayanan baru berbasis digital. Sehingga warga lembaga pendidikan Islam dapat dengan leluasa mengakses segala keperluan terkait pendidikan dan layanan administrasi. Contoh lainnya, mengembangkan model pembelajaran kekinian dengan sepenuhnya memanfaatkan teknologi digital, seperti E-learning, Blended Learning, dan sebagainya. Dengan demikian, lembaga madrasah berupaya memberikan tawaran solutif kepada pelanggang dalam menghadapi Era Revolusi Industri 4.0. Sebagaimana dikertahui bersama, bahwa era 4.0 membawa dampak yang luas dalam segala lini kehidupan, tak terkecuali dalam bidang pendidikan. Era yang melahirkan 
fenomena disruption ini menuntut dunia pendidikan Islam untuk turut menyesuaikan diri. Lulusan madrasah kini dihadapkan pada tantangan, tuntutan, dan kebutuhan baru yang belum pernah ada sebelumnya. Sehingga perlu dilakukan pembaruan dan inovasi terhadap sistem, tata kelola, kurikulum, kompetensi sumber daya manusia, sarana dan prasarana, budaya, etos kerja, dan lain-lain.

Menurut Wakil Ketua Persatuan Guru Nahdlatul Ulama (Pergunu), Aris Adi Laksono menanggapi Hari Pendidikan Nasional 2019. Aris, untuk menjawab era disrupsi pola pendidikan pesantren dan madrasah sudah membuktikannya dengan langkah-langkah sebagaimana dipaparan Jeffrey H Dyer, Hal B Gregersen, dan Clyton M Christensen (2013) dalam buku The Innovator's DNA. Dalam buku tersebut dikemukakan lima) Discovery Skill of True Innovatoryakni associating; questioning, observing, experimenting, and networking."Associating adalah kemampuan berfikir asosiasi. Sederhananya, kemampuan menghubungkan bidang ilmu, masalah atau ide, dimana orang lain memandangnya tidak berhubungan, dalam menyelesaikan setiap masalah, kata Aris, harus selalu ditinjau dari berbagai presfektif atau multidisipliner.

Berikutnya questioning atau kemampuan bertanya yang sangat penting, namun terabaikan selama ini. Kemampuan mengamati (observing skill). Selanjutnya, kemampuan melakukan percobaan (experimenting skill). Seorang innovator selalu mencoba pengalaman baru dan mengemudikan ide-ide baru tersebut. "Bagi mereka, tidak ada kegagalan, semua ketidakberhasilan melakukan eksprimen merupakan sebuah kesuksesan yang tertunda. Keterampilan terakhir adalah kemampuan melakukan jejaringan (networking skill). Para inovator menghabiskan banyak waktu dan energi untuk menemukan dan menguji ide-ide melalui berbagai jaringan individu dan sosial yang berbeda latar belakang dan prespektif, mencari secara aktif ide-ide baru dengan berbincang bersama orang yang memberi pandangan tentang sesuatu yang secara radikal berbeda.

Pesantren dan madrasah merupakan lembaga pendidikan Islam yang memiliki posisi penting di Indonesia. Sebagai negara dengan penduduk mayoritas beragama Islam dan penduduk muslim terbesar di dunia, lembaga pendidikan Islam tersebut memiliki peranan dalam meningkatkan kualitas kemanusiaan penduduk muslim di Indonesia. Jika tidak demikian, madrasah akan semakin tertinggal dan usang. Oleh karena itu, perlu dicari langkah-langkah kongkrit bagi madrasah untuk meningkatkan mutu agar mampu tetap 
bersaing di era disrupsi ini. Langkah solutifnya adalah dengan turut mendisrupsikan diri, ${ }^{63}$ tanpa lepas dari indentitas sebagai lembaga pendidikan Islam yang mempunyai karakteristik dan haruslah berpegang teguh pada kaidah al-muhafadhah 'ala al-qadim ashshalih wa al-ahdzu bi al-jadid alashlah, yaitu menjaga tradisi keagamaan Islam dengan teguh melestarikan segudang khazanahnya dan memakai metode, manajerial, maupun pembelajaran modern yang baik.

\section{Kesimpulan}

Kesimpulan besar yang bisa ditemukan dalam makalah ini adalah dunia institusi pendidikan madrasah mempunyai banyak persoalan, oleh karena itu, aplikasi pada sistem manajemen mutu yang berbasis 4.0 dalam meningkatkan kualitas untuk melahirkan produk yang mempunyai kecerdasan kognitif dan afektif, psikomotorik serta mendisrupsikan diri dalam era 4.0. belum maksimal, memerlukan kebijakan pemerintah dengan menyediakan anggaran yang cukup, sehingga madrasah dapat menghidupi para guru-gurunya, melengkapi sarana dan prasarana pendidikannya, menyediakan buku-buku pelajarannya yang berbasis digital, insya Allah persoalan ini dapat terselesaikan. Undang-Undang Sistem pendidikan Nasional yang berhasil disahkan beberapa tahun lalu, kiranya memberikan peluang bagi pemerintah memberikan perhatian secukupnya terhadap seluruh lembaga penyelenggara pendidikan, termasuk pendidikan madrasah. Madrasah dengan segala kelemahan dan kekurangannya, pada hakekatnya ia dibangun atas dasar niat tulus dan jernih yaitu mengantarkan putra-putrinya selain agar cerdas dan trampil serta berwawasan luas, juga agar berkesempatan mengenali ajaran agamanya (Islam) secara cukup, yang dilakukan terus menerus dalam peningkatan kualitas.

${ }^{63}$ Lihat Sigit Priatmoko, Memperkuat Ekstensi Pendidikan Islam Era 4.0 dalam jurnal Studi Pendidikan Islam, Ta'lim, Vol. 1 No.2, 2018 
| SAMSUL BAHRI | Pendidikan Madrasah Berbasis 4.0 ...

\section{Daftar Pustaka}

Azra, Azyumardi, Pendidikan Islam Tradisi dan Modernisasi Menuju Milinium Baru, Jakarta, Logos Wacana Ilmu, 2000. , Islam Substantif: Agar Umat Tidak Jadi Buih, Bandung: Mizan, 2000 , Paradigma Baru Pendidikan Nasional Rekonstruksi dan demokratisasi, Jakarta, Kompas, 2002.

Abdur Rahman Shaleh, Madrasah dan Pendidikan Anak Bangsa; Visi, Misi dan Aksi, Jakarta, Rajagrafindo Persada, 2006.

Dauly, Haidar Putra, Historisitas dan eksistensi Pesantren, Madrasah, sekolah, Yogyakarta, Tiara Wacana, 2001.

Fajar, A. Malik, Visi Pembaharuan Pendidikan Islam, Jakarta, LP3NI, 1998. , Madrasah dan Tantangan Modernitas, Bandung, Mizan, 1998.

Fattah, Nanang, Standar Pembiayaan Pendidikan, Bandung, Remaja Rosdakarya, 2012. , Sistem Penjamin Mutu Pendidikan, Bandung, Remaja Rosdakarya, 2012 , Analisis Kebijakan Pendidikan, Bandung, Remaja Rosdakarya, 2012

Hanun, Asrohah, Sejarah Pendidikan Islam di Indonesia, Jakarta, Logos wacana Ilmu, 2001.

Husni, Rahim, Madrasah dalam Politik Pendidikan di Indonesia, Jakarta, logos, 2005.

Jauhar, Vol I. No. 1, Desember, 2000.

Maksum, Madrasah dan Sejarah Perkembangannya, Jakarta, Logos, 1999.

Mastuhu, Memberdayakan Sistem Pendidikan Islam, Jakarta, Logos Wacana Ilmu, 1999.

Muhaimin, Pengembangan Kurikulum Pendidikan Agama Islam, di Sekolah, Madrasah, dan Perguruan Tinggi, Jakarta, Raja Grafindo Persada, 2007.

, Pengembangan Kurikulum Pendidikan Agama Islam, di Sekolah, Madrasah, dan Perguruan Tinggi, h. 2000.

, Wacana Pengembangan Pendidikan Islam, Yogyakarta, 2003. 
Rahim, Husni, Arah Baru Pendidikan Islam di Indonesia, Jakarta, Logos wacana Ilmu, 2001.

Rhenald Kasali, Disruption "Tak Ada yang Tak Bisa Diubah Sebelum Dihadapi Motivasi Saja Tidak Cukup” Menghadapi Lawan-Lawan Tak Kelihatan dalam Peradaban Uber. Jakarta: PT Gramedia Pustaka Utama, 2017,

Shaleh, Abdur Rachman, Madrasah dan Pendidikan Anak Bangsa, Visi,Misi dan aksi, Jakarta, Raja Grafindo Persada, 2006.

Stanton, Charles Michael, Pendidikan Tinggi dalam Islam, Jakarta, Logos, 1994.

Steenbrink, Karel A. Pesantren, Madrasah, dan Sekolah, Jakarta, LP3ES, 1986.

Suwito, "Kurikulum Berbasis Kompetensi", dalam makalah seminar sambutan atas nama Rektor UIN Syarif Hidayatullah, Jakarta, pada acara Workshop, pada Program Studi Agribisnis Fakultas Sains dan Teknologi, Jakarta, 17 April 2003.

Sigit Priatmoko, Memperkuat Ekstensi Pendidikan Islam Era 4.0 dalam jurnal Studi Pendidikan Islam, Ta'lim, Vol. 1 No.2, 2018

Yatim, Badri, dkk, Sejarah Perkembangan Madrasah, Jakarta, Depag RI, 1999.

Yunus, Mahmud, Sejarah Pendidikan di Indonesia, Jakarta, Pustaka Mahmudian, 1960.

Defening Quality in Education oleh UNICEF tahun 2000

Understanding Education Quality, dalam EFA Global Monitoring Refort Chapter 1, tahun, 2000,

Kementrian Agama, Desain Pengembangan Madrasah, Jakarta: Direktorat Jendral Kelembagaan Agama Islam, 2005

Fadjar, A.M. (1998). Madrasah dan tantangan modernitas. Bandung: Mizan

Fandy Tjiptono \& Anastasia Diana, Total quality management (TQM). Yogyakarta: Penerbit Andi2003

Furchan, A, Transformasi pendidikan Islam di Indonesia: Anatomi keberadaan Madrasah dan PTAI. Yogyakarta: Gama Media, 2004.

Greenwood, M.S. and Helen J.G, Total quality management for school. Wiltshire: hassell,1994

Nurhayati Djamas, Madrasah mandiri. Jakarta: Puslitbang Pendidikan Agama dan Keagamaan. 2005.

Sallis, E. Total quality management in education. Philadelphia: Cogan Page,1993 
| SAMSUL BAHRI | Pendidikan Madrasah Berbasis 4.0 ...

Soegito, Total Quality Management. Semarang: UNNES, 2002.

Soewarso Hardjosoedarmo,Total quality management. Yogyakarta: Andi. 2002

Umedi, Manajemen mutu berbasis sekolah/madrasah (MMBS/M). Jakarta: Pusat Kajian Mutu Pendidikan,2004.

Bambang Hadi Wiardjo dan Sulistijarningsih Wibisono Memasuki pasar internasional dengan ISO 9000, sistem manajemen mutu. Jakarta: Ghalia Indonesia, 1996.

Bonstingl, J.J. Quality of school. California: Corwin Press, 2001.

Bush, T., Theories of educational management. London: Paul Chapman Publishing, 1986.

\section{Sumber internet}

Zaskia, "Beberapa kelemahan mendasar madrasah”, izaskia.wordpress.com/.../beberapakelemahan-mendasar-madrasah-1/ - dalam Google.com 11 Januari 2013, 11.23 pm

www.dikdasmen.depdiknas.go.id,: h. 7-8 diakses tanggal 7 Januari 2012

Artikel Bulletin Pengawasan No 13\&14 Tahun 1998, http: www.google.co.id diakses tanggal 7 Januari

Disampaikan pada Pelatihan Supervisi Pendidikan Madrasah Ibtidaiyah dan Tsanawiyah Tahun 2001, BEP Depag di Pusat Pendidikan Infantri, Bandung.2 Sekretaris Ditjen Kelembagaan Islam, Depag. 